\title{
Management and Social Problems Linked to the Human Use of European Urban and Suburban Forests
}

\section{Ewa Referowska-Chodak (D)}

Department of Forest Protection, Institute of Forest Sciences, Warsaw University of Life Sciences (SGGW), ul. Nowoursynowska 159, 02-776 Warsaw, Poland; ewa_referowska_chodak@sggw.pl; Tel.: +48-22-5938169

Received: 20 September 2019; Accepted: 29 October 2019; Published: 1 November 2019

\begin{abstract}
This review regards the management and social problems in European urban and suburban forests linked to their maintenance and human use. They can be divided into major categories: forest management problems (e.g., the low priority of urban forestry, various or diffused urban forest management, lack of management plans or lack of sufficient funds); the social reception of forest works and forests (e.g., emotional reactions to total clear-cutting, negative evaluation of logging traces, negative evaluation of poor tourist infrastructure, specific expectations concerning a model forest: e.g., tall, of low density, mixed, old); and relations between forest users (problems related to e.g., crowding, fast-moving people, the presence of dogs, littering, thefts or noisy behaviour). Here, special attention is paid to problems and negative interactions, as they are challenges to forest management, as well as to the development of plans, strategies, and policies, both in relation to existent forests and those planned in various parts of Europe. Taking into account the feelings and expectations of forest users concerning forests, forest works/management, and infrastructure, as well as their attitude to other forest users, may reduce conflicts concerning various kinds of forest perception and use, and (with the support of societal education) may help to increase the sense of social responsibility for the "shared" forests. The presented findings are expected to be practical and useful for the management of urban and suburban forests, regardless of the location, as a type of checklist of possible problems, that may prove to be important and up-to-date in a particular location.
\end{abstract}

Keywords: management problem; urban forest; suburban forest; conflict; urban forestry

\section{Introduction}

In Europe, urban forests in the form of communal, city, or town woodlands have a long history of conservation and management [1]. Theoretically, urban forestry is focused on providing urban communities with psychological, sociological, economic, and aesthetic benefits of forests, so it places the needs of people above those of trees [2-4]; however, this priority is not so evident everywhere.

The aforementioned human needs in relation to forest use have evolved (e.g., [5-8]) and they have changed with the progress of civilization, from the initial pragmatic needs (e.g., fuel, food reserves) to the current ones, also including higher-level needs (e.g., aesthetic values, nature conservation, hobbies). This is associated with more free time being available than in the past, the increasing wealth of society, and the rise of environmental consciousness (e.g., [2,6,9-11]). Additionally, current trends in tourism, which most strongly affect the use of urban and suburban forests, are linked to a return to nature, care for health (e.g., active pastimes, activation of elderly people), and a polarization of interests $[2,8,9,12]$. Therefore, the presence of forests in the vicinity of the place of residence (in and around towns and cities) makes it possible to meet these diverse needs of people and to respond to modern trends in tourism.

The cover of urban and suburban forests between European cities may range from less than $1 \%$ to more than $75 \%$ [13-16]. However, regardless of whether urban or suburban forests are extensive or 
fewer in number, they always have values important for the society, related to all ecosystem services: supporting, provisioning, regulating and cultural. These ecosystem services and values of forests (presented below), are shaped in the process of forest management.

The environmental value of urban and suburban forests (as a place where you can connect with nature, biodiversity) is related to supporting services (services necessary for the production of all other ecosystem services $[17,18])$. Each forest has such a value for the society $([19,20]$, e.g., in the United Kingdom [21], Finland [9,22,23], Austria [24,25], Switzerland [12], Poland (e.g., [4,7,26-28]), Slovenia [29], Sweden [6,30], the Netherlands [31], and Norway [31]). Urban and suburban forests are often habitats of diverse (also rare and valuable) species of plants, fungi, and animals (e.g., [32-35]). The high environmental value of selected forests inspires some of the visitors or forest managers to undertake conceptual or/and practical measures aimed at their protection (e.g., $[9,27,36,37])$.

The material value (picking of mushrooms and berries, timber production, etc.) is related to provisioning services (products obtained from ecosystems [17,18]). Picking of forest fruits is simultaneously of recreational value (e.g., $[6,7,9,38]$ ). Timber harvesting brings some material benefits $[6,9,11,22,39]$, but in developed countries, it is usually less important than the social functions of forests (e.g., $[1,3,6,22])$. Hunting is the activity the least frequently mentioned $[6,30,38,40,41]$.

The health value of urban and suburban forests (barrier against noise, shade, clean air, and water) and the safety value (reducing the risk of natural disasters) consist in regulating services (benefits obtained from the regulation of ecosystem processes $[17,18])$. In the first case (health value), urban forests create a specific microclimate; protect against air pollution and have a soothing and healing influence on organisms exposed to the everyday pressure of crowded conditions, noise, and haste ([2,19,20,42], e.g., in the United Kingdom [21,43], Finland [9,22,23], the Czech Republic [38], Turkey [44], Switzerland [12], Poland (e.g., [3,7,26,27,45]), France [40], Austria [24], Sweden [6], the Netherlands [31], and Norway [31]). In the second case (safety value), urban forests stabilize the soil, preventing its erosion, but also reduce the effects of storm water runoff (through canopy retention and infiltration) or winter wind; sequester carbon; and moderate the urban microclimate $[26,46,47]$. This is important because natural disasters generate socio-economic losses [48]. Urban trees can save up to $10 \%$ of energy consumption through their moderation of climate $[46,47]$.

The different types of values of urban and suburban forests related to cultural services (nonmaterial benefits obtained from ecosystems $[17,18])$ are particularly numerous. The first one is the aesthetic value (beauty) - the different structures and diversities of forests enrich the appearance of urban areas and change their landscape, improving the aesthetic impressions of their inhabitants $([2,19,20]$, e.g., in Finland [9,22,23], the Czech Republic [38], or in Poland [3,4,7,49]). The second is the spiritual value (feelings, memories) - forests arouse positive feelings, such as admiration, sense of freedom, respect for life, and a sense of place ([2,19], e.g., in the Czech Republic [38], Switzerland [12], Finland [23], Slovenia [29], Sweden [30], or in Poland [49]). People need the feeling of unity with nature (e.g., $[21,26,49])$. The third one is the recreational value. Urban and suburban forests are a place for rest, tourism, sports, and playing - among others strolls, Nordic walking, outdoor games, jogging, cycling, horse riding, picnics, geocaching [2,42,50], e.g., in the United Kingdom [21], Finland [9,22,23,36,51], Switzerland [12,41], Austria [24,25], the Czech Republic [38], Turkey [44], Poland (e.g., [7,26,28,52,53]), France [40], Sweden [6,39], Norway [31,37], or in the Netherlands [31]. Most of the activities also have a positive influence on health. Besides, forests located near cities and towns are attractive venues for sports events, e.g., jogging, cycling, or orienteering races [52,53]. The fourth is the educational value (forest as a place where natural objects and processes can be observed) - there are many educational facilities in urban and suburban forests, and managers of the forests organize environmental events for various age groups (e.g., [38,47,54]). The fifth one is the historical and cultural value of places linked to historical events and culture-forests were sites of many battles and shelters for soldiers and partisans, and there are also cultural and religious objects and events/traditions in woodlands. Those aspects are important for some visitors (e.g., $[7,9,36,55])$. 
Due to their importance (cf the aforementioned values), their closeness, and their accessibility, urban and suburban forests are particularly intensively used by the society and their significance is still increasing [42], e.g., in Austria [25], the Czech Republic [38], Poland (e.g., [8,54,56,57]), Sweden [39,58], Finland [36], and the United Kingdom [58], or selected Southeast European cities [59]. In contrast to areas mostly attractive to holidaymakers, those forests are important for people all year long, often every day (e.g., in the United Kingdom [21], Finland [9,22,60], Austria [25,61,62], the Czech Republic [63], Poland (e.g., [7,28,52,64]), or Norway [65]). This phenomenon, as well as the continuous development of cities and related infrastructure, results in problems not only related to pressure on both inanimate and animate nature (e.g., deforestation, fragmentation, habitat alteration, or introduction of alien species [66,67]), but also related to social and management issues resulting from historical, legal, organizational and financial conditions, but also from the expectations, needs and feelings of people using these forests. For example, an obstacle to good forest management may often be the lack of sufficient data about forests and the phenomena occurring in them [68], which leads to the loss of biodiversity [69] at the same time reducing the aforementioned environmental value of forests. Another problem is the inappropriate strategic policy: the lack of a strong legislative framework, institutional capacity, and substantial financial resources to support appropriate forest management [68]. Sometimes, these matters change a lot throughout history, e.g., the period of socialism and its collapse in the countries of Central and Eastern Europe [70]. In the case of social issues, the intensive use of urban and suburban forests by various city and town dwellers generates some problems with interpersonal relations (e.g., $[24,61])$, but these negative feelings can also be addressed to foresters (forest managers) if, for example, the appearance of the forest (the aforementioned aesthetic value) does not meet the expectations of forest users. It is noteworthy that in the published literature, this kind of problems is presented only narrowly, focusing most often on one or few aspects. There are no literature items that comprehensively describe the problems people face in urban and peri-urban forests: on the one hand, related to the management of such forests and, on the other hand, related to the use of these forests (from the social point of view). Meanwhile, they are most often closely interlinked, creating a complex manager-forest-user relationship, which should be taken into account in the management of urban and suburban forests. This represents a major challenge for forest management planners and forest managers, and requires a careful preparation and a particular attention to present and possible future problems.

In response to the above-mentioned need, this review is aimed at providing a comprehensive overview of the management and social problems linked to the human use of European urban and suburban forests, including negative interactions between humans themselves or humans and forests (relations between forest users, as well as the social reception of forest works and forests). In the discussion and conclusions an attempt was made to determine the influence of various factors on the mentioned problems, as well as the interrelationship between the manager, the forest and the user. An awareness of these situations makes it possible to improve forest management: forest management planners and forest managers may use them as some type of checklist of possible problems to check whether they are up-to-date and important in a particular location. The paper is focused on suburban and urban forests in the narrow sense: only the woodland elements of urban green structures [1], i.e., the areas covered with natural forest vegetation [22,51], without parks, gardens, or trees along the streets.

\section{Methods}

The methodology of information search, applied in this literature review, is analogous to that used in the author's article on pressures and threats to nature related to human activities in European urban and suburban forests [67]. Thus, these articles complement each other and cover all issues associated with the management of urban and suburban forests in Europe.

The first literature search was conducted in April-May 2018, using the search engine on the web page of the Forest Research Institute in Warsaw [71] (search words in Polish in all forms: "urban forest"; 
titles of articles, keywords and descriptors were scanned). This broad preliminary search resulted from the fact that the studied subject was often only presented in a "by the way" manner, while discussing another main issue. The timeframe of the search was not predefined. This yielded a total of 318 articles, but only some of them (41, from 1993 to 2017) were relevant to the main subject of this review and met the following criteria for inclusion in the results: location (urban or suburban forest in Europe); type of urban/suburban forest (woodland); the described, or at least mentioned, problem (management or social problem linked to the human use of European urban and suburban forests); the quality of the source of information (peer-reviewed research and review articles-international or national ones, items published by known publishing houses or international institutions, reports, thesis); and the language of the text or abstract/summary (English, French, or Polish). Sources of information concerning urban and suburban forests outside Europe as well as parks, gardens, trees along streets and problems other than related to management and human use of forests, did not meet quality criteria; Likewise, sources published only in languages other than English, French or Polish were not taken into account (excluded). The inclusion and exclusion criteria were firstly applied to the literature body on the keyword, title, and descriptors level. If the keyword, title, and/or descriptors were unclear, the full text of the body was screened. The inclusion and exclusion criteria were subsequently applied on a full text level to screen for relevance of the literature body for the review.

The second literature search was conducted in August 2018, using the search engine of Scopus [72] and combining the search words "urban forest" AND "problems" or "urban forest" AND "threats" (titles of articles, abstracts and keywords were scanned). The timeframe of the search was not predefined, but the countries/territories have been limited to only European ones. This process yielded 57 articles from European countries (and additionally one publication common with the first search), but only some of them (9, from 2005 to 2017) met the abovementioned criteria for inclusion. Supplementary literature concerning problems with urban and suburban forests was located using the snowballing method: when important information for the results appeared in the basic source, cited after another source, this second source was also searched and reviewed for this and additional important information (using the same criteria). In some cases-to add a background, to control the scope of literature for selected topics, or to discuss the results-some searches were carried out using detailed keywords, related to the obtained results (e.g., hunting in urban forest). The timeframe of all searches was not predefined. Mainly thanks to the snowballing method, another 32 literature items were added to the results. Finally, 82 literature items were cited to present the main results (Figure 1, Tables 1-4). They refer primarily to individual states, but sometimes also to larger regions, like Eastern Europe or the (hemi)boreal vegetation zone. Some articles referred to different regions of Europe (in the Results, it is mentioned as "Europe") or different regions of the world, including Europe (it is mentioned as "globally"). All of these types of locations are included in Tables 1-4. The literature review was also used to identify the importance of urban and suburban forests for people, which has been presented in the Introduction. 


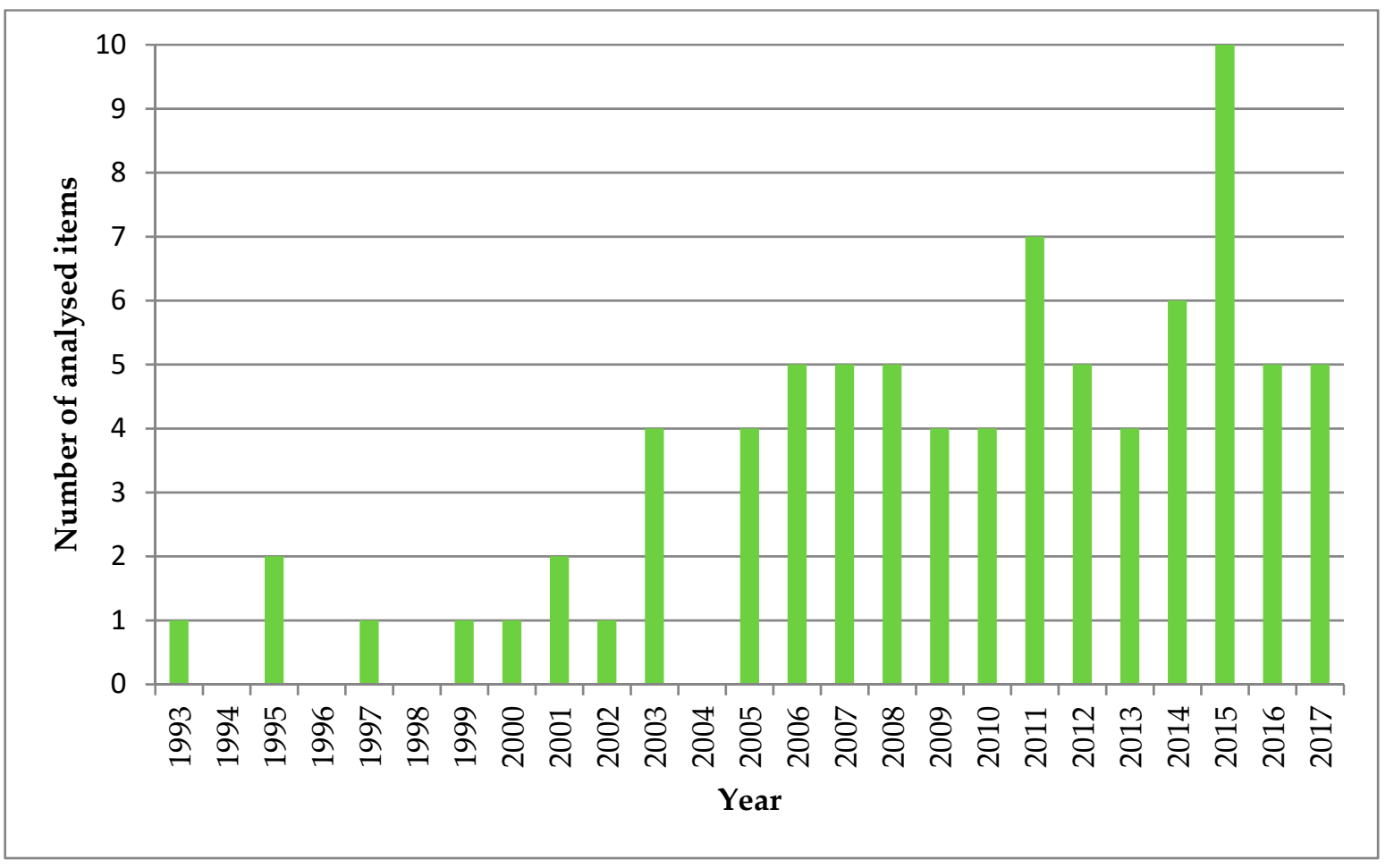

Figure 1. Time distribution of materials concerning the European region, cited in the results.

The synthesis and analysis of data was conducted manually. Data extracted from the selected 82 literature bodies included bibliographic details (author, title, publication data, the source title, volume, pages etc.), the diagnosed problem (management or social problem linked to the maintenance and human use of European urban and suburban woodlands) as well as the location of the diagnosed problem (particular state, region of Europe, Europe). The mentioned problems included all circumstances and situations that hinder or prevent planning and/or the implementation of forest management, as well as negative impressions and feelings of people using forests, resulting from the forest management practices or from the presence of other forest users. This information was either the main subject of the studied issue, or was presented as an aside while discussing another main issue. The collected information has been grouped basing on shared threads across the literature into the main thematic sections: forest management problems; social reception of forest works and forests; and relations between forest users. Then, detailed categories were set for them (specific and unique problems), and the states or regions of Europe in which they were noted are presented (Tables 1-4).

The subsection "Forest management problems" details the author's analysis of the nature of each problem (Figure 2). Two questions were posed: what does the problem result from and what does the problem influence? After the initial analysis of the literature and the critical analysis of individual cases' descriptions, the following six factors were distinguished: history (in the sense of historical conditions that have affected the problem, as it can be related to, e.g., the political history of the country), ownership (in the sense of the influence of various forms of ownership on forest management), law (in the sense of current problems or needs within the legal framework for the organization and implementation of forest management in urban and suburban forests), concepts (in the sense of a lack of or problems with the forest management concepts creation, e.g., whether it should include social participation or make some restrictions on the use of forests to city dwellers), implementation (in the sense of problems with the implementation of the aforementioned concepts due to, e.g., the lack of staff or founds), and funds (in the sense of insufficient funds). The cause and influences of each of the problems were determined basing on the information from the reviewed literature. Since every urban and suburban forest in Europe is very individual in terms of the problems that may be associated with its management, not all of the relationships in Figure 2 happen to be 
applicable. This is due to the fact that Figure 2 is the sum of observations from different places in Europe, described or derived from reviewed literature.

In the two last thematic sections ("Social reception of forest works and forests"; and "Relations between forest users"), as part of the author's analysis of the results obtained, directions of negative relations (DNR) between humans and urban/suburban forests were specified to show the high complexity of the issues discussed in the article (Tables 2 and 4). A similar solution has been adopted in the abovementioned review concerning pressures and threats to nature related to human activities in European urban and suburban forests [67]. The following question has been raised: considering each particular issue, what are the possible ways of negative interactions in the forest/people system? Four directions may be distinguished (all possible): "humans to forests" (when people negatively affect forests), "forests to humans" (when forests, their components, negatively affect people or their impressions), "forests to forests" (when some components of the forest have a negative impact on others due to disturbances originating from human activity), and "humans to humans" (when people interact negatively one another in a direct way or by interfering with the functioning of the forest). The definition of the direction of negative relations was based on the description of the problem in the studied literature. It should be noted that a problem may have more than one DNR assigned to it. For example, "Emotional reactions to total clear-cutting" (Table 2) - "FH" ("forests to humans") annotation means that the appearance of the forest has a negative impact on the aesthetic sense of the forest user, while "HH" ("humans to humans") means that the forest user feels negative emotions towards the forester/forest manager about the appearance of the forest. Awareness of these DNR can be useful during planning and implementing forest management, because it can limit some conflicts related to the use of urban and suburban forests by people.

In the case of subsection "Relations between forest users", the intensity of negative relationships between people (forest users) has been assessed (Table 4). Two possibilities were taken into account: discomfort (when people feel uncomfortable because of other people's behaviour) and threat (when the other people's behaviour poses a danger to people's health and the sense of security).

\section{Results and Discussion}

\subsection{Forest Management Problems}

Forest policies, which arise from real or perceived problems, create the legal, regulatory, and operational environments for forest management, guiding the actions employed in this management [73]. An effective forest policy should make it possible to fulfil various needs and solve conflicts between forest nature conservation and use by the society (e.g., [2,29,39,74,75]). In many countries, however, the lack of forest policies and a legal basis for forest management within urban areas is noticeable [27,44,76,77], as the number of legal acts concerning them is excessive [74]. This generates specific problems of urban forest management (Table 1). 
Table 1. Problems of forest management in urban and suburban forests.

\begin{tabular}{|c|c|c|}
\hline No. & Problem & Region and Citation \\
\hline 1 & $\begin{array}{l}\text { Treating urban forestry as a secondary activity, with a } \\
\text { low priority-in some cases the people responsible for } \\
\text { forests are not interested in them, and do not carry out } \\
\text { tending operations and protective measures }\end{array}$ & $\begin{array}{l}\text { The United Kingdom [78], Poland [79], Eastern } \\
\text { Europe [59], Globally [19,42] }\end{array}$ \\
\hline 2 & $\begin{array}{l}\text { Lack of precise documentation of municipal forest areas } \\
\text { and borders-the lack of sufficient data results e.g., in the } \\
\text { loss of biodiversity }\end{array}$ & Poland $[57,80]$, Greece $[81]$ \\
\hline 3 & $\begin{array}{l}\text { Unsettled ownership of some forests, which prevents } \\
\text { planning and implementation of forest management }\end{array}$ & Poland $[57,80]$ \\
\hline 4 & $\begin{array}{l}\text { Various forms of forests' ownership in cities, which make } \\
\text { consistent forest management difficult, especially when } \\
\text { stakeholders are not willing to cooperate }\end{array}$ & $\begin{array}{l}\text { Sweden [30], Serbia [74], Poland }[27,54,79,82] \text {, } \\
\text { Europe }[1,2]\end{array}$ \\
\hline 5 & $\begin{array}{l}\text { Public ownership of some forests makes decision-making } \\
\text { a multifaceted task and dependent on various } \\
\text { administrative, political, and participatory processes }\end{array}$ & Finland [11] \\
\hline 6 & $\begin{array}{l}\text { Various or diffused urban forest management, } \\
\text { e.g., municipal or county office workers, managers of } \\
\text { urban green areas, departments of urban roads }\end{array}$ & $\begin{array}{l}\text { The United Kingdom [78,83], Finland [11], } \\
\text { Poland [3,77,79], Eastern Europe [59], } \\
\text { Europe [84], Globally [19] }\end{array}$ \\
\hline 7 & $\begin{array}{l}\text { Poor communication amongst local authority } \\
\text { departments, forest managers, which hinders planning } \\
\text { and implementation of forest management }\end{array}$ & The United Kingdom [78,83], Europe [84] \\
\hline 8 & $\begin{array}{l}\text { Fragmentation of extensive woodlands, which makes } \\
\text { forest management difficult }\end{array}$ & Poland $[27,57,79,80]$, Serbia $[74]$ \\
\hline 9 & $\begin{array}{l}\text { Lack of management plans for smaller urban forests or } \\
\text { faulty legal acts (or lack of a strategic approach) } \\
\text { concerning the preparation of them }\end{array}$ & Denmark [85], Poland $[27,57,77,80]$, Europe [14] \\
\hline 10 & $\begin{array}{l}\text { Legal tools too week to supervise forests effectively, e.g., } \\
\text { in the case of problems with health state of forests }\end{array}$ & $\begin{array}{l}\text { Poland }[4,27,57,80,82] \text {, the United } \\
\text { Kingdom [83], Europe [14] }\end{array}$ \\
\hline 11 & $\begin{array}{l}\text { Insufficient staff to supervise forests effectively, e.g., in } \\
\text { case of illegal use of them }\end{array}$ & $\begin{array}{l}\text { The United Kingdom [78,83], Italy [14], } \\
\text { Poland }[57,79,80,86]\end{array}$ \\
\hline 12 & $\begin{array}{l}\text { Difficulties with defining forests in cities (forest or urban } \\
\text { green area?) }\end{array}$ & Poland $[57,80]$, Europe [42] \\
\hline 13 & $\begin{array}{l}\text { Lack of standard methods of urban forest management, } \\
\text { including procedures or systems for forest health } \\
\text { monitoring }\end{array}$ & $\begin{array}{l}\text { Poland }[3,7,27,77,80] \text {, Serbia [74], the United } \\
\text { Kingdom [78], Europe [42] }\end{array}$ \\
\hline 14 & $\begin{array}{l}\text { Lack of sufficient funds for the implementation of forest } \\
\text { management (especially in smaller towns), i.e., for the } \\
\text { preparation of forest management plans }\end{array}$ & $\begin{array}{l}\text { Poland [79], Germany [74], the United } \\
\text { Kingdom [78,83], Denmark [87], Serbia [59], } \\
\text { Europe [2,14,42], Globally [19] }\end{array}$ \\
\hline 15 & $\begin{array}{l}\text { Lack of sufficient funds for the development of } \\
\text { recreational infrastructure and environmental education, } \\
\text { especially in smaller towns }\end{array}$ & $\begin{array}{l}\text { Poland }[4,57,79,82] \text {, Serbia [59], Europe [2], } \\
\text { Globally }[88]\end{array}$ \\
\hline 16 & $\begin{array}{l}\text { Higher costs of garbage collection and removal from } \\
\text { forests due to the large number of urban forest users }\end{array}$ & Germany [89], Poland [86] \\
\hline 17 & $\begin{array}{l}\text { Difficulties in forest works in urban and suburban forests } \\
\text { due to the large numbers of tourists and other } \\
\text { visitors-this mostly applies to suburban forests, where } \\
\text { the scale of such operations is larger }\end{array}$ & Poland [52] \\
\hline
\end{tabular}

In Figure 2, forest management (FM) problems are analyzed, taking into account their nature: what do they result from? (red lines) and what do they influence? (blue lines). Their numbers correspond with numbers from Table 1. As mentioned in Methods, the following six factors were distinguished (on the central part of the figure): history (historical conditions that have affected the problem), ownership (the influence of various forms of ownership on forest management), law (actual 
problems or needs), concepts (a lack of or problems with concept creation), implementation (problems with the implementation of concepts, and forest management), and funds (insufficient funds). How to read this figure? For example, low priority of urban forestry (Problem no. 1) may result from (red line) historical conditions (HISTORY) and may influence (blue line) the implementation of urban forest management (IMPLEMENTATION). However, it should be stipulated (see Methods) that due to the individuality of European urban and suburban forests, not all these relationships must be valid for every forest.

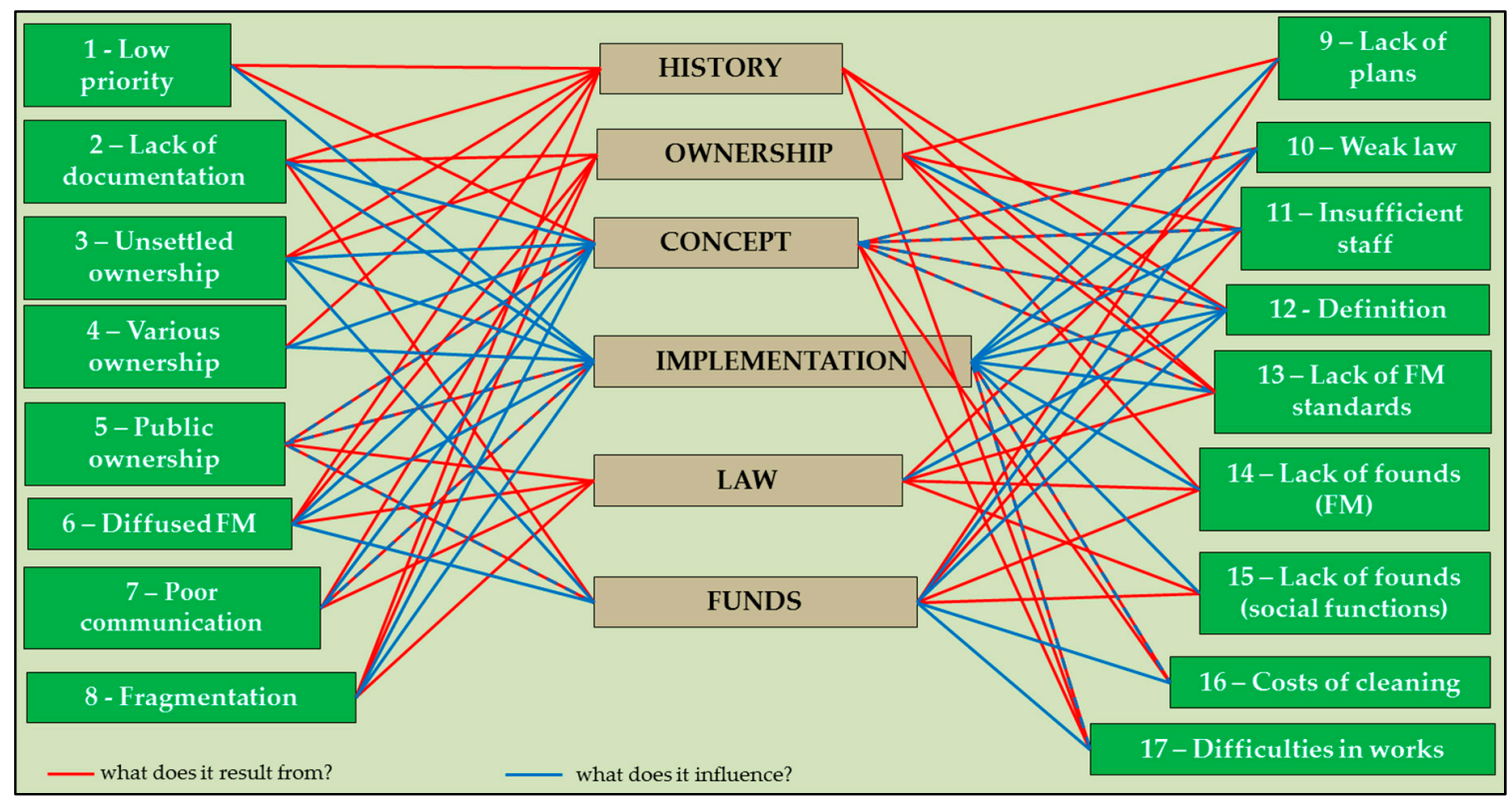

Figure 2. The analysis of forest management problems from Table 1.

The presented problems (Table 1) are usually complex, sometimes dependent on each other, and in each case affect the quality of management of urban and suburban forests (Figures 2 and 3). Here are some examples. Of the 17 analyzed problems of urban and suburban forest management (Figure 2), nine result from historical conditions; nine are associated with a form of ownership; and in five cases, both the conditions are important. In Europe, although urban forests (woodlands) owned by the local community generally have a long history of woodland conservation and management [1], the situation is not the same everywhere. For example, after the collapse of socialism in Central and Eastern Europe in the 1990s, the privatization of forest lands increased the forest cover loss due to logging. Such changes have been observed, e.g., in Estonia, Latvia, Slovakia, Hungary, Slovenia, Lithuania, Romania, Bulgaria, the Czech Republic, and Poland [70]. In and around cities, this pressure was (and still is) especially strong because of attractive neighborhoods (in cities, it is usually easier to earn money and have access to all the achievements of technology and culture) [27]. Additionally, limited urban planning, institutional failures regarding public urban forests planning and management (Problem no. 6), and limited investments in such goods (Problems no. 1 and 14) resulted in a decline of those forests, which earlier-with other green spaces—were abundant in socialist countries [59]. In other regions of Europe, interlinked historical and ownership conditions also have an impact on forest management. For example, the large-scale owner structure in the UK (landscape history: feudalism with strong landowning aristocrats) results in a landscape scale of management in British guidelines, as well as in restricted accessibility to private forests, and an important role of experts in the visual management of the landscape. Meanwhile, in Sweden, the small-scale owner structure (landscape history: no feudalism, self-owning peasants, weaker aristocrats) results in an ecosystem scale of management in Swedish guidelines, as well as in open access to private forests ("everybody's recreational landscape"), and visual management of the landscape in reference to public preferences [58]. Disregard for social 
preferences in forest management, especially in public forests, can lead to problems (dissatisfaction and conflicts) in some regions (Problem no. 5, Section 3.2) (e.g., [5,36,90]). Unsettled ownership (Problem no. 3) or various ownership (Problem no. 4) of urban and suburban forests (as the result of historical conditions-e.g., $[4,82])$ is also an obstacle for correct forest management-this hinders or prevents coordinated work, e.g., for forest protection [27]. Similarly, a different understanding of the term "urban forests" (Problem no. 12) may be historically conditioned-this will have consequences for both law-making and urban forestry concepts and their implementation [42].

Another cause of the urban forest management problem is the law, which is either incomplete (some solutions are missing) or imperfect (existing solutions are unclear) or very demanding). As it was mentioned above, legal problems may arise from the lack of a clear definition of urban forests (Problem no. 12). For example, in Poland so far, the Act on Forests does not define urban forests as a separate category of forests. The consequence of this is the lack of legal provisions taking into account the specificity of these forests, the lack of a uniform system of supervision over urban forests (Problems no. 6 and 7), both at national and city levels, and the necessity for forest managers to rely on several other laws in addition $[77,80]$. Moreover, current legal solutions are not conducive to ensuring sufficient funds for the maintenance of forests (care and protection measures) (Problem no. 14) and of the infrastructure, including tourist infrastructure (Problem no. 15) [79]. Sometimes laws, rules and regulations adopted increase the time and the effort required to prepare a management plan for urban and suburban forests (Problem no. 5). For example, in Finland in many municipalities the planning process is participatory. There is no single model for participatory planning, but there are described cases that could serve as a model. However, this does not guarantee that all stakeholders will be satisfied with the process, as demonstrated by the Puijo experience, where the following four factor groups (from those engaged to those problematic) have been identified: "supporters of systematic planning approach", "the representatives quiet majority", "the co-operation skeptics" and "frustrated participants" [36].

The lack of concept refers to various topics. One of them is the low priority of urban forestry (Problem no. 1), resulting e.g., from the assumption (concept) that management planning for these forests is not very important [84]. Standards of forest management (among others, methods of managing or organizing forestry work) also depend on the adopted forest management concepts-in the absence of such concepts, these standards often do not exist (Problem no. 13). For example, if management measures change continuously, the targets set by management plans will probably not be reached because of problems with vegetation adapting to the new conditions [84]. The lack of some forest management standards in guidelines may e.g., make it impossible to implement a visual concept of the urban or suburban forest [58]. A coherent approach (concept) to the management of urban and suburban forests can be hampered by imperfect legislation (Problem no. 10), e.g., allowing deforestation [27], as well as by the lack of resource inventories (Problem no. 2) [42] and diffused forest management (Problem no. 6) [80].

The lack of funds is also important (in six problems-Figure 2), and it is a growing problem for private and public forestry in Europe [42]. For example, insufficient funds for environmental education of the society (Problem no. 15) may deepen some problems resulting from the low ecological awareness of forest users. It concerns, among others, vandalism of natural objects, littering (Problem no. 16), and intentional or unintentional ignition, which are widespread problems in European urban and suburban forests (e.g., $[21,52,67,91]$ ) as well as the lack of understanding of forestry works, including tree felling (e.g., [82]). It also concerns large-scale mushroom picking (especially in Slavic and Scandinavian countries, Romania, Switzerland, and Italy) and mushroom poisoning, which are more regional problems, depending on the local tradition of using wild edible fungi [67,92-94]. The lack of funds may also block the repair of tourist infrastructure destroyed by vandals, as well as the creation of additional infrastructure (Problem no. 15) (e.g., [4,79]) to resolve some of the social problems presented in Section 3.3: crowding and very intensive and diverse use of forests, which are noted more often in urban than suburban forests [7]. In the last case (lack of new infrastructure), it may also be related 
to the lack of forest management plans (Problem no. 9) which should include a uniform concept of recreational infrastructure [80], which in turn is affected e.g., by diffused forest management (Problem no. 6), various ownership of forests (Problem no. 4) and the need to prepare a number of specific documents [27]. The lack of sufficient funds may also be the cause of insufficient staff (Problem no. 11) (e.g., [79]), which makes it difficult to limit the mentioned vandalism, but also poaching [86]. In general, when current and future funding is not secured (Problem no. 14), the long-term management is not guaranteed [84].

All the analyzed problems (Table 1 and Figure 2) influence the implementation of urban and suburban forest management, and most of them (11 problems) also hinder or modify the determination of the concept of the management. The lack of precise documentation of some of these forests (Problem no. 2), among others, results in inappropriate handling of them, not adapted to the real conditions, and on a larger scale, results in the lack of aggregate current (and regularly updated) data about forests in and around European cities, including their area and the quality of management [14,42]. Additionally, when the decision-making process is difficult, and dependent, among other things, on various groups of interests' needs (Problems no. 5 and 6), there are some problems with hunting, which can reduce damage to the forest from herbivores and which often meets with public opposition, especially from city dwellers [2]. In turn, communication problems (Problem no. 7), as well as conceptual ones in the management of described forests (Problem no. 13), may be an obstacle, e.g., in determining and maintaining wildlife corridors, which requires broader spatial planning and cooperation of forest managers with other officials [95]. Similarly, the cooperation with city authorities and the local community (by participatory planning) (Problems no. 5-7) and better legal tools (Problem no. 10) are needed to reduce deforestation, fragmentation, and isolation of forests (Problem no. 8), and to lead afforestation [96]. When urban forestry is treated as a secondary activity, with a low priority (Problem no. 1), there is no motivation for tree selection to decrease pollen production or to increase the resistance of forests to pollution. However, this can lead to very serious negative health consequences for people. Pollen, mainly from Fagales, Lamiales, Proteales, and Pinales, may cause allergic reactions, which are a widespread and actual problem of many people in Europe, especially in industrialized societies within the temperate climate zones [97]. In the case of air pollution, it depends on the region of Europe [98]. The largest shares of dwellers living in polluted parts of cities are in Malta (40\%), Greece (36.3\%), and Germany $(32.5 \%)$. In the case of towns and suburbs' dwellers, the worst situation is in Greece (24.9\%), Luxembourg (20.7\%), and Germany (20.3\%) [13]. Increasing the priority of these problems in urban and suburban forest management and taking into account the selection of appropriate tree species [14,99], will enable the health value of forests to be maintained.

The presented problems also have an impact on financial issues (in seven problems), in most cases increasing management costs (e.g., when there are difficulties in forest works due to the large numbers of visitors-Problem no. 17) or limiting the availability of financial resources (when legal tools are too weak-Problem no. 10). Although the costs of maintenance, protection, and recreational management of urban and suburban forests (Problem no. 14) are high and exceed the profits from timber production $[2,9,37,57,89]$, it should be noted that these costs (including rubbish collection-Problem no. 16) are significantly lower than the value of benefits from these forests. In Joensuu and Salo (Finland), for example, the value of benefits from selected forests, determined using the WTP (Willingness-to-pay) method, was seven to 23 times higher (in the case of recreational value) than the cost of maintaining these forests [22].

\subsection{Social Reception of Forest Works and Forests}

From the perspective of urban forest managers/foresters, urban forestry (management) focuses on maintaining a variety of functions, from timber production to nature conservation and recreation, with a special emphasis on this last function [42,84]. This is why creating (and maintaining) a diverse and attractive forest image is mostly the main goal of urban forests management [84]. In the case of timber production, its significance in urban woodlands is not as essential as in the traditional 
output of forestry [42,84]; however, regionally, it is also quite important, e.g., in Finland [22] or Belgium [84]. Urban forestry has adopted the principle of sustained yield from traditional forestry by achieving and maintaining a balanced age structure of forests, and ensuring continuous tree cover and sustained provisioning of goods and services for city dwellers [42]. Woodland may be managed in many ways, including non-intervention, especially in the case of some parts of larger forests. It is noteworthy that high forests are closer to nature (and require less cost) than coppice and the form- and species-rich, many-layered woodland types are especially valuable types for urban contexts [84]. To obtain woodlands which are valuable in terms of the physical landscape, ecological, and aesthetic matters, as well as to regenerate them and balance the age structure of forests or for timber production (especially in suburban forests), some cuttings are needed, e.g., thinning or selection cutting $[84,100]$. Forest management also covers other issues, such as making the forest available to the public (construction of tourist infrastructure) [3]. All these activities can arouse the various emotions of forest users, including negative ones (Table 2).

Table 2. Negative social reception of forest works in urban and suburban forests.

\begin{tabular}{|c|c|c|}
\hline DNR $^{1}$ & Main Problem & Region and Citation \\
\hline $\mathrm{HH}$ & $\begin{array}{l}\text { The low public acceptance of forest works } \\
\text { primarily related to cutting trees (as a } \\
\text { negative interference in "our" forest) }\end{array}$ & $\begin{array}{l}\text { Finland }[36,60,90], \text { Austria [24], France [2], } \\
\text { Sweden }[6,90], \text { Norway }[37,90], \\
\text { Poland }[7,53,54,57,82,101]\end{array}$ \\
\hline $\mathrm{FH}, \mathrm{HH}$ & Emotional reactions to total clear-cutting & $\begin{array}{l}\text { Denmark [5], Finland [5,36,90], Iceland [5], } \\
\text { Norway [5,90], Sweden }[5,30,90,102], \\
\text { Europe [103] }\end{array}$ \\
\hline $\mathrm{FH}, \mathrm{HH}$ & $\begin{array}{l}\text { Negative evaluation of logging traces (lower } \\
\text { recreational attractiveness of forests) }\end{array}$ & $\begin{array}{l}\text { Germany [89], Finland [60,90], Norway [90], } \\
\text { Sweden [75,90], Europe [103] }\end{array}$ \\
\hline $\mathrm{HH}$ & $\begin{array}{l}\text { Well-defined (although sometimes conflicting) } \\
\text { opinions of town/city dwellers about forest } \\
\text { management, including negative evaluations }\end{array}$ & $\begin{array}{l}\text { Poland [7,53], Croatia [59], The Czech } \\
\text { Republic [38], Bosnia and Herzegovina [59], } \\
\text { Sweden [30,102], Serbia [59,104], France [2], } \\
\text { Montenegro [59], Finland [36,60], } \\
\text { Macedonia [59], Europe [2] }\end{array}$ \\
\hline $\mathrm{FH}, \mathrm{HH}$ & $\begin{array}{l}\text { Specific expectations concerning a model } \\
\text { forest (Table } 4 \text { - source of conflicts between } \\
\text { forest managers/owners and users) }\end{array}$ & $\begin{array}{l}\text { Germany [105], The United Kingdom [21], } \\
\text { Europe [2] }\end{array}$ \\
\hline $\mathrm{HH}$ & $\begin{array}{l}\text { Negative evaluation of an insufficient amount } \\
\text { or poor quality of recreational/tourist } \\
\text { infrastructure, e.g., narrow footpaths, shared } \\
\text { sections of walking, and cycling trails }\end{array}$ & $\begin{array}{l}\text { Croatia [59], The Netherlands [31], } \\
\text { Poland [7,28,56,64,79,106], Bosnia and } \\
\text { Herzegovina [59], Austria [24], Serbia [59], } \\
\text { Montenegro [59], Macedonia [59], Europe [9] }\end{array}$ \\
\hline $\mathrm{HH}$ & $\begin{array}{l}\text { Negative evaluation of recreational/tourist } \\
\text { infrastructure (when some visitors prefer } \\
\text { unmanaged forests) }\end{array}$ & $\begin{array}{l}\text { Finland [23], France [40], Sweden [6,75], } \\
\text { Norway [37], Poland [7,107], } \\
\text { The Netherlands [31] }\end{array}$ \\
\hline $\mathrm{HH}$ & $\begin{array}{l}\text { Negative reaction to restrictions, introduced } \\
\text { by forest managers, e.g., closing (temporary } \\
\text { shutdown) of some tourist trails or limiting } \\
\text { the possibility of collecting mushrooms }\end{array}$ & $\begin{array}{l}\text { Poland [28,53], Switzerland [41,92], } \\
\text { Austria [24], Europe [2] }\end{array}$ \\
\hline $\mathrm{HH}$ & $\begin{array}{l}\text { Negative evaluation of forest management } \\
\text { activities as a nuisance factor }\end{array}$ & Austria [24] \\
\hline $\mathrm{HH}$ & Negative evaluation of hunting & $\begin{array}{l}\text { The United Kingdom [108], Switzerland [41], } \\
\text { Europe [2] }\end{array}$ \\
\hline
\end{tabular}

The presented people's negative impressions about forest works (DNR:FH and DNR:HH—Table 2) are associated with negative visual and auditory stimuli they are sensitive to (both related to nature and infrastructure/forest works/foresters), and result also from the required level of comfort and forest accessibility, or emotional feelings affected by high ecological sensitivity and the desire to protect "wild" 
nature. People have well-defined opinions not only about urban and suburban forests management (Table 2), but also about the appearance of forests (Table 3).

Table 3. Social preferences concerning the appearance and quality of urban and suburban forests.

\begin{tabular}{|c|c|}
\hline Attribute of Forest & Region and Citation \\
\hline Not too small—a minimum of 2 ha in size & $\begin{array}{l}\text { Serbia [59], Montenegro [59], The United Kingdom [21,109], } \\
\text { Bosnia and Herzegovina [59], Macedonia [59] }\end{array}$ \\
\hline Tall (with large trees, mature) & $\begin{array}{l}\text { Poland [26], Finland [23,90], Sweden [75,90], Norway [90], } \\
\text { Europe }[103,110]\end{array}$ \\
\hline Light & Poland [26] \\
\hline Of low density ("open") & $\begin{array}{l}\text { The United Kingdom }[2,21,109] \text {, Poland }[26,107] \text {, } \\
\text { Finland }[22,90], \text { The Czech Republic }[38,63], \text { Germany }[89] \text {, } \\
\text { Sweden }[39,75,90] \text {, Norway [90], Europe }[50,103]\end{array}$ \\
\hline Mixed & $\begin{array}{l}\text { The Czech Republic [38], Poland [26], The United } \\
\text { Kingdom [21], Germany [89], Europe [103,110] }\end{array}$ \\
\hline Old (with large trees, mature) & $\begin{array}{l}\text { Poland [26,107], Sweden [30,75,90,102], The United } \\
\text { Kingdom [2], Finland [23,90], Germany [89], Norway [90], } \\
\text { Europe [103,110] }\end{array}$ \\
\hline Dry & Poland [107] \\
\hline $\begin{array}{l}\text { Without dense undergrowth, which reduces the } \\
\text { sense of security }\end{array}$ & $\begin{array}{l}\text { The United Kingdom [21,109,111], Sweden [39,90], } \\
\text { Finland [22,23,60,90], Poland [54,112], Denmark [87], } \\
\text { Norway [90], Europe [2,50,103] }\end{array}$ \\
\hline With different sceneries (variation along the path) & $\begin{array}{l}\text { The Czech Republic [38], Finland [90], Norway [90], } \\
\text { Sweden [90], Europe [103] }\end{array}$ \\
\hline With naturalistic forest edges & Europe [103] \\
\hline $\begin{array}{l}\text { Rich in non-wood forest products, } \\
\text { particularly mushrooms }\end{array}$ & Poland $[7,26,107]$ \\
\hline $\begin{array}{l}\text { "Well maintained" (not "neglected" or "ugly, with } \\
\text { broken boughs and branches"; small amount of } \\
\text { deadwood; without falling trees or branches) }\end{array}$ & $\begin{array}{l}\text { The United Kingdom [21], Norway [37,90], } \\
\text { Finland [23,60,90], Sweden [39,75,90], Poland [7,112,113], } \\
\text { Slovenia [114], Europe [103], Globally [115] }\end{array}$ \\
\hline With a small number of mosquitoes, ticks, and ants & Poland [7] \\
\hline
\end{tabular}

The widespread nature of negative people's evaluation of forests' appearance (DNR:FH) and of forest managers/foresters (DNR:HH) in Europe (Table 2) is primarily based on the visible forest landscape (Table 3), which is influenced by forest management and forest works. It is noteworthy, that the negative attitude of forest users to forest managers mainly results from the fact that foresters are held responsible for the unsatisfactory (from the users' point of view) appearance of the forest.

Negative impressions of forest users about forest landscape (and the work of forest managers/foresters) may be due to the fact that the forest is considered to be, alternatively:

- Too natural-people feel the fear of the wildness of nature, when there is a large amount of deadwood, fallen trees, and branches, which are the attributes of a natural forest [116,117]. Additionally people in some regions of Europe got used to a "traditional" appearance of the forest without deadwood [118], which is why they assess such a forest with deadwood as "neglected, mismanaged". However, the role of deadwood in the proper functioning of the forests is essential $[84,118,119]$, and its volume is even an indicator of the pan-European criteria for sustainable forest management [119]. The topic of deadwood seems to be worth a wider consideration. It is known that resources of deadwood are variably spread across Europe [119], but there is no analogic full data for urban and suburban forests, apart from some single ones [113]. Meanwhile, the information about its amount can be used to assess the ecological value (quality) of a given urban/suburban forest. People also dislike some forest species (e.g., moose, invertebrates in Norway) or are afraid of animals that are large, predatory, poisonous, carrying diseases, evoking 
disgust, and animals that in cultural heritage, were considered to be heroes of negative myths (e.g., bats), wherein attitudes towards forest animals are often contrasted [120,121]. People are also afraid of dense undergrowth (limited view, fear of some animals [121]). It is noteworthy, that the reduced sense of security and threatened health (e.g., [122-124]) limits human wellbeing [125]. However, the dense and mysterious coppices, capable of regenerating themselves easily in case of damage, are considered inspiring and robust environment for children's games [111];

- Too much transformed-for people, e.g., visible traces of cutting/logging decrease the aesthetic and recreational value of the landscape [126], and disturb the sense of place, which is the spiritual value of a forest (see Introduction). Negative and emotional reactions to cutting/logging are particularly specific to inhabitants of larger towns and cities all over the Europe, i.e., the main users of the discussed forests $[2,6,7,54,112]$. This may result from the public opinion that urban and suburban forests should allow rest and recreation, rather than timber harvesting (e.g., [7,42,101,127]). Timber production in urban forests is indeed lower than in commercial forests [22,79]; however, it must be remembered that forest management modifies not only habitats $[34,39,60,69,128-132]$, but also the landscape, which determines the suitability of forest stands for recreation $[31,64,103,133]$;

- Not matching the favorite model — this model (Table 3) may slightly vary, depending on the region of Europe, local cultural norms, and methods of forest management, which influence biophysical factors [103]. The presented preferences are relatively narrow and in some cases contradict the principles of sustainable forest management [134], which are important in urban forestry [88]. It was mentioned that the form- and species-rich, many-layered woodland types are especially valuable types for urban contexts [84]. This means that in some cases, the spatial structure of forests should be enriched, e.g., by the introduction of a shrub layer or a lower tree layer [2]. It can make a difference to society, because forest vegetation (especially the above mentioned dense undergrowth) affects the perception of personal safety [50]. It is noteworthy that this ideal forest is also not eternal, and the forest should be regenerated. After the phase of preferred old, mature, and tall trees is a phase of less appreciated young, low, and thin trees. Forest works also change the attributes of an ideal forest, which additionally may not match the local habitat, the principles of forest management, or protection needs. These are further situations in which a conflict may arise between forest managers and forest users. On the other hand, societal preferences concerning forest structure should form a basis for the assessment of the recreational usefulness of forests [135].

The last of the above-mentioned points (a forest not matching the favorite model) may additionally be influenced by the amount and quality of tourist infrastructure or by the accessibility of the forest (Table 2). The presence of recreational infrastructure in urban forests is usually positively evaluated by their users (e.g., in the Czech Republic [38], Poland [28], Germany [89], Norway [37,90], Finland [90], and Sweden [90], or in the (hemi)boreal vegetation zone [136]). Some negative impressions may appear when the amount of infrastructure is insufficient or too abundant, and its quality is poor $[7,28,59,64,106]$ or it is destroyed by vandals. The lack of understanding of the needs of urban societies in this field may lead to conflicts between them and forest managers [2]. Negative reactions of forest users are also related to restrictions in the accessibility of the forest [24,92], regulated by local or national law $[24,92,137])$, introduced by forest managers to protect the ecosystems or to protect people during forest works.

The presence of forests is commonly associated with a high value and naturalness of the environment [53], and their aesthetic value is very important for citizens (e.g., [2,7,38]). The high demands of people for urban forest appearance, goods, and services in relation to a small resource base that are widespread in Europe may result in conflicts, which are a challenge for urban foresters to resolve [42]. It is noteworthy that the management of urban and suburban forests should take into account the people's needs [2-4] and the management visions should be accepted by all the main stakeholders [84]. However, it is not simply when land (forest) managers have other (different) opinions than forest users about forests and forest management [2]. 
Some of the presented problems, like antipathy against selected animal species and the lack of acceptance of deadwood or acceptance of forest management activities, may be mitigated by environmental and forest education; however, this requires constant funding, which is sometimes not evident (Table 1-Problem no. 15).

\subsection{Relations between Forest Users}

Since the large numbers and closeness of houses, schools, and workplaces, urban forests are usually visited more often than suburban ones [7,25,127]. However, the impact of town/city dwellers on forests is not limited to urban forests. In fact, inhabitants of urban areas are ready to cover longer distances to get to their favorite forest, even up to $100 \mathrm{~km}[7,9,38,56,127]$, although many people choose forests located close to their home, easily accessible by transport [2,42], e.g., in the United Kingdom [21,109], Finland [22], Austria [24,25], the Czech Republic [38], Poland [7,64], Denmark [87], Slovenia [29], Sweden [6], or Norway [65]. Particularly large numbers of people visit urban and suburban forests in warmer seasons during weekends, especially on Sundays [7,24,25,56]. When many people use a relatively small area of forests, some discomforts and threats in their interpersonal relations can appear (Table 4).

Table 4. Discomforts (D) and threats (T) in relations between users of urban and suburban forests.

\begin{tabular}{|c|c|c|}
\hline DNR $^{1}$ & Main Problem & Region and Citation \\
\hline $\mathrm{HH}, \mathrm{HF}$ & $\begin{array}{l}\text { The presence of other } \\
\text { people (D) }\end{array}$ & $\begin{array}{l}\text { Croatia [59], Austria [24,61], Bosnia and Herzegovina [59], } \\
\text { Switzerland [41], Serbia [59], Montenegro [59], Poland [7,28], } \\
\text { Macedonia [59], Europe [2] }\end{array}$ \\
\hline $\mathrm{HH}, \mathrm{HF}$ & $\begin{array}{l}\text { Very intensive and diverse } \\
\text { use of forests-the possibility } \\
\text { of conflicts }(D, T)\end{array}$ & Austria [61], Switzerland [41], Germany [89], Sweden [30], Europe [2,9] \\
\hline $\mathrm{HH}, \mathrm{HF}$ & $\begin{array}{l}\text { Fast-moving people (e.g., on } \\
\text { bike or horse) (D, T) }\end{array}$ & $\begin{array}{l}\text { Austria }[24,61] \text {, The Netherlands [31], Switzerland [41], Poland [7,56], } \\
\text { Europe }[2,9]\end{array}$ \\
\hline $\mathrm{HH}, \mathrm{HF}$ & Crowding (D) & $\begin{array}{l}\text { Croatia [59], Serbia [59], Austria [24,25,61,62], Bosnia and } \\
\text { Herzegovina [59], Turkey [44], Poland [7,28,54], Macedonia [59], } \\
\text { The Netherlands [31], Montenegro [59] }\end{array}$ \\
\hline $\mathrm{HH}, \mathrm{HF}$ & $\begin{array}{l}\text { The presence of dogs } \\
\text { (especially non-leashed) and } \\
\text { dog feces }(D, T)\end{array}$ & $\begin{array}{l}\text { Austria [24,61], Croatia [59], The United Kingdom [2], Bosnia and } \\
\text { Herzegovina [59], Switzerland [41], Poland [7], Montenegro [59], } \\
\text { Slovenia [114], Macedonia [59], Finland [23] }\end{array}$ \\
\hline $\mathrm{HH}, \mathrm{HF}$ & Littering (D) & $\begin{array}{l}\text { Croatia [59], Austria [24], Bosnia and Herzegovina [59], The United } \\
\text { Kingdom [2], Serbia [59], Poland [7,28], Montenegro [59], Finland [22,23], } \\
\text { Slovenia [114], Macedonia [59] }\end{array}$ \\
\hline $\mathrm{HH}$ & $\begin{array}{l}\text { Damage to infrastructure, } \\
\text { sign of vandalism }(D, T)\end{array}$ & $\begin{array}{l}\text { Croatia [59], Austria [24], Serbia [59], Montenegro [59], Poland [7,28,64], } \\
\text { Bosnia and Herzegovina [59], Finland [23], Slovenia [114], } \\
\text { Macedonia [59], Globally [138] }\end{array}$ \\
\hline $\mathrm{HH}, \mathrm{HF}$ & Threat of fire $(\mathrm{T})$ & Poland [7], Europe [42] \\
\hline $\mathrm{HH}$ & Thefts $(\mathrm{T})$ & Poland [7], The United Kingdom [2] \\
\hline $\mathrm{HH}$ & Assaults (T) & The United Kingdom [2] \\
\hline $\mathrm{HH}, \mathrm{HF}$ & Noisy behaviour $(\mathrm{D}, \mathrm{T})$ & $\begin{array}{l}\text { Austria [24,25,61,62], Serbia [59], Turkey [44], Macedonia [59], } \\
\text { Finland [23], Bosnia and Herzegovina [59], Poland [7,28], Croatia [59], the } \\
\text { Netherlands [31], the United Kingdom [2], Norway [31], Montenegro [59] }\end{array}$ \\
\hline $\mathrm{HH}$ & Prostitution (D) & The United Kingdom [2] \\
\hline $\mathrm{HH}, \mathrm{HF}$ & $\begin{array}{l}\text { Using motor vehicles in } \\
\text { forests }(D, T)\end{array}$ & The United Kingdom [2], Poland [54,57,82], Europe [2] \\
\hline $\mathrm{HH}$ & $\begin{array}{l}\text { Anti-social behaviours of } \\
\text { other people (without details) }\end{array}$ & Finland [22] \\
\hline
\end{tabular}


It is noteworthy that most of the problems presented in Table 4 are widespread (and actual) in Europe, regardless of the region, history, and culture of particular societies.

Distinguishing between behaviours that cause discomfort or pose a threat is often subjective, depending on the sensitivity of people who use urban and suburban forests. Women have significantly higher fear levels than men, and the presence of youth gangs, sexual offenders, or thieves, and signs of negligence or physical incivilities (e.g., abandoned cars, graffiti, vandalism) additionally increase the feeling of crime [138]. Table 4 shows a more objective, realistic assessment of the presented problems. It takes into account that in some circumstances, discomfort can become a threat. For example, if a fast-moving cyclist or motorcyclist is not careful, they can cause an accident and hurt a pedestrian. In turn, damage to infrastructure may become a threat, when it limits the stability of infrastructure construction. The noisy behaviour can be discomfort for men, and for women-a threat. This is due to the fact that women have significantly higher fear levels than their male counterparts, and it is associated (among other things) with the presence of disorderly persons at a particular site [138]. Some situations, however, are undoubtedly dangerous and this applies to dissocial behaviours, such as theft, fire-raising, or assaults.

Negative interactions between forest users themselves (DNR:HH) may be caused by the feeling of competition, differences in people's sensitivity, and a disturbed sense of security. The feeling of competition concerns, inter alia, the access to limited goods, such as fungi, forest fruits, or game, especially those collected on a massive scale in regions with strong traditions [137]. In the case of mushroom hunting, as was mentioned above (Section 3.1), the problem of competition between forest users may occur, especially in Slavic and Scandinavian countries, Romania, Switzerland, and Italy, but also, e.g., in Latvia and Hungary [92-94]. When the immediate interests of individuals are in potential conflict, there is no place for altruism, understanding the needs of others, and taking into account the future [139].

Due to the differences in sensitivity, some people have greater needs in terms of the quality of rest in forests, which play an important therapeutic role, exerting positive effects on physical and mental health $[12,140,141]$. After a walk in the forest, the level of stress decreases, the well-balanced feeling rises $[12,140,141]$, and the heart function improves $[140,141]$. However, the effectiveness of therapy may be influenced by silence, peace, and loneliness. In this last case, it is noteworthy that only a small group of forest users are the social stimulation-tolerant ones [62]. Due to the uncomfortable crowded situations, visitors (especially the crowding-averse ones) employ coping behaviors, like intra-area displacement (choosing other trails or walking off-trails), inter-area displacement (travelling to other green spaces), temporal displacement (changing visiting time), activity displacement, shortening the duration of visits to forests, or putting their dog on a leash [24]. It is noteworthy that not only people's physical presence in forests may be a discomfort, but also just traces of their visits, like litter or signs of vandalism, which are a common problem in many European countries (especially littering), regardless of the level of wealth of residents, and require continuous ecological education.

The disturbed sense of security may be related to non-compliance with legal norms (almost always it will be a threat), and to non-compliance with social norms (depending on the intensity, it will be a threat or a discomfort). The first one primarily includes vandalism (in relation to plants [21], mushrooms [92,137], or animals [142]), thefts, assaults, motor vehicles use, fire-raising, and the presence of unleashed dogs (when they have to be on a leash). In extreme cases, people may feel the fear of crime, which can have potentially important influences on their mental health and wellbeing [138]. There is a lack of European statistics about the number of crimes in urban and suburban forests. Therefore, it is difficult to assess the real scale of the phenomenon and the role of these forests as places of crimes. In the greater Baltimore region [143] and some other regions in the USA [144], there is a strong inverse association between crime rates and tree canopy cover, which is stronger in the case of public land. However, these studies concern broadly understood urban forests, including roadside and garden greenery. It would be practical to know the following statistics: is the feeling of crime often accompanying people justified? In the case of forest fires, which can be deadly for people [145], 
it is noteworthy, that only in Spain, Italy, and Poland, are deliberate fires (i.e., caused intentionally by people) the most frequent cause. In other countries, fires are also the effect of human activities, but rather unintentional [145], and in this case-as an imprudent handling of fire-they can be classified as non-compliance with social norms (if the use of fire was allowed in a given place at all).

The second cause of the disturbed sense of security (non-compliance with social norms) includes fast-moving people, noisy behavior, and the presence of unleashed dogs. Some dogs attack people, but there are no statistics about dog attacks on people in European urban and suburban forests. Some research in the USA indicated that people were more disturbed by large dogs, like Rottweilers, Doberman Pinschers, Pit Bull Terriers, and Chows, but in general, they felt comfortable with unleashed dogs. Additionally, leashed dogs initiated contact with humans 5.5 times more than unleashed ones [146]. In Europe, it is quite often highlighted that unleashed dogs are negatively perceived by users of urban and suburban forests, e.g., in Vienna [24,61] or selected Southeast European cities [59]; however, most visitors of selected urban forests in the Netherlands and Norway did not believe that dogs constituted any threat or difficulty [31]. Most often, the non-compliance with social norms is related to egoistic behavior of people, which makes it difficult to solve such conflicts of interests [139]. Additionally, the presence of beggars, homeless persons, and drunkards, is assessed very negatively. The anti-social behaviour results in people being unable to enjoy the pleasures of visiting urban green spaces [138].

Most of the problems presented in Table 4 in terms of the relations between users of urban and suburban forests (DNR:HH) also rebound on forests (DNR:HF). Apart from fires, which have a very negative impact on forests' landscape, ecosystems, and species, and are indicators of forest degradation [147], the main problem is the simultaneous presence of many people, who are often quite noisy. This generates some negative pressures on the soil (especially its erosion [148]), vegetation (e.g., damage due to trampling [149]), and animals (especially scaring [52,89]). In the latter case, not only the presence of people, but also the dogs that accompany them, is important. Scaring wild animals by dogs, especially free-ranging, leads to stress, harassment, and sometimes death [150]. It is noteworthy that dog owners do not understand the problem fully. In a survey conducted in the Czech Republic, more than $37 \%$ of participants suggested that the presence of dogs in forests should not be limited in any way [38]. In none of the studies touching the problem of the man-dog relationship in European urban and suburban forests were the threats to wildlife posed by dogs mentioned.

\section{Conclusions}

Approximately two-thirds of the world's population will be living in an urban area by 2050; in Europe, this share will grow at a slower rate than in Africa and Asia to just over 80\% [13]. This shows that the matter of urban green space is of increasing importance [2,44].

In this review, about 80 sources of information were used to present organizational problems of European urban and suburban forest maintenance and negative interactions between humans or humans and forests (in the case of relations between forest users, as well as the social reception of forest works and forests). They were reported from some states or regions of Europe, listed in Tables 1-4. However, because of the differences between countries in the intensity of publishing research works at international level [88], the identification of the actual range of described problems requires a review of the literature published in nationally ranked journals (in this article it was done for Poland). Perhaps using other databases of scientific publications (e.g., Web of Science, ScienceDirect) would also make it possible to supplement this and other information presented in the article, for example the analysis of forest management problems (Figure 2).

On the basis of this review, separate articles with analysis of each problem (or group of problems) can be developed in the future, using international articles from databases like Scopus, ScienceDirect, Web of Science or others, as well as articles published in nationally ranked journals. It would be useful to focus on the presented problems in greater detail, e.g., by exploring what their current range and importance are, what do they result from and what do they influence depending on the region/state, 
how they are interlinked or who and how should look for a solution to them. There is also a need for broader research: how the process of forests management and human use is determined by local historic, legal and planning conditions, funding structures as well as the process of decision-making in different countries and what impact do these conditions have on the effectiveness of forest management, especially in practical terms? How the urban-forest decision-making process actually works in different European countries, what problems are encountered in that decision-making, and how those problems might be addressed? Such information and described experiences, translated into English in case of articles published in nationally ranked journals [14], could provide a valuable database useful in forest management.

The presented problems and interactions create a complex manager-forest-user relationship, which, in a simplified way, is presented in Figure 3. Some of these relations are one-way, which means that the interaction takes place in only one direction. For example, the form of forest ownership may influence the way it is managed, but forest management will not change the form of forest ownership. Similarly, from the professional point of view, the forester has a shapely influence on the forest, but the forest does not change the forester. The situation is different in the case of two-way relations, when the interaction takes place in both directions (Figure 3). For example, the amount and quality of tourist infrastructure may influence the level of forest users' comfort, but at the same time users can influence the amount and quality of the infrastructure through e.g., vandalism. Similarly, the forest management influences forest users' impressions (creating a specific appearance and accessibility of the forest), at the same time the user may — through participatory planning-influence the management method. These relations and problems are important, up-to-date and represent challenges to forest management and the development of plans, strategies, and policies, both in relation to existent forests and those planned in various parts of Europe (e.g., [40,87,151,152]).

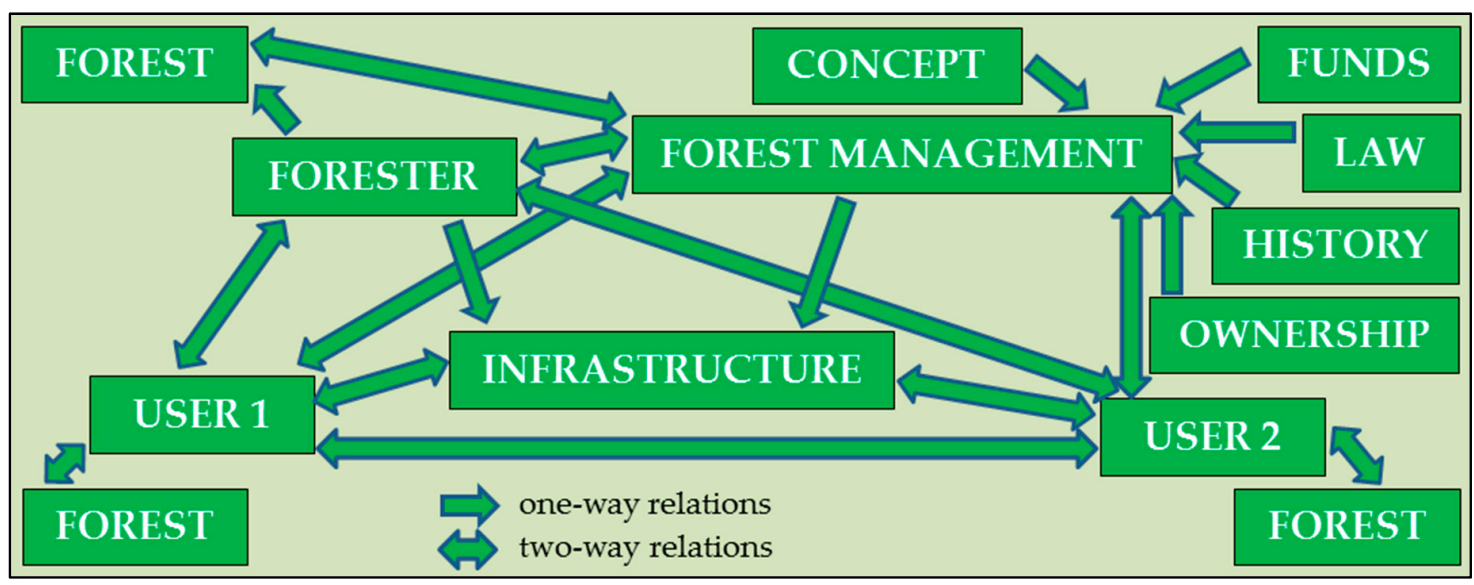

Figure 3. The complex manager-forest-user relationship in urban and suburban forests.

The process of forest management is strongly dependent on the local, regional and, finally, national context in legal, social or even cultural terms. This is why solutions to the presented problems should be primarily searched for at the national and local (municipal or community [2,14]) level. At the national level, effort should be made to clarify the definition of urban forests; to increase their priority; to improve legislation on forest management and accessibility; and to establish basic standards for forest management (including planning, forest work, employment of staff) and financing. At the local level, efforts should be made to improve documentation and knowledge about forests; to reduce forest fragmentation; to increase the safety of people in forests; and to resolve social conflicts related to forest management and use. For foresters/forest managers, these measures will be particularly important at both levels, while for city and town dwellers-rather those at the local level, especially in terms of increasing their safety and reducing conflicts and dissatisfactions related to forest management and use. It is noteworthy, that some of the needed efforts (e.g., improving legislation or financing) 
depend not only on foresters, but require broader cooperation of forest managers with other institutions and officials.

From the point of view of reducing social conflicts and dissatisfaction (related to forest management and use), three types of action seem to be of particular importance: public participation in forest management planning ("participatory planning"; at the local level), public education (at national and local levels) and implementation of technical (infrastructural) solutions (at the local level). They seem to be useful regardless of the location in Europe, although they should be implemented in a way that takes into account specific local conditions.

Participatory planning means managing forests in cooperation with various stakeholders and social groups, e.g., the owners of the forest, the forest industry, locals, enterprises or organizations engaged in tourism, sport, culture, and nature protection [2,20,36,42]. It is recommended and realized only in some European countries, e.g., in Finland [22,36,60,153], Sweden [6,30,102,154], Serbia [104], Germany [74], or Norway [37]. Forest managers should remember that users of urban and suburban forests have well-defined preferences in respect of the place and form of recreation, as well as the place-specific spatial values, and the non-spatial and nonplace-specific spatial values [30]. Simultaneously they often have a negative attitude towards forest management (logging in particular). Managers of public forests (which by definition should be accessible to everybody) should especially pay attention to this and at least partly take into account users' expectations and emotional relationship to woodlands [111]. Participatory planning allows a compromise (trade-off) between the needs of different interest groups, including forest managers. It is noteworthy that particularly in the Nordic countries (including Denmark, Sweden, Iceland, Norway, and Finland) there is a strong tradition of research into forest preferences of the general public and of visual management of urban woodlands by reference to these preferences [58]. There are also well described experiences related to conducting the procedure of participatory planning (e.g., [30,102,154]) and its evaluation (e.g., [36]). They are a valuable source of information for other countries that have just started or plan to start such an approach to forest management planning. Such a procedure allows conflicts concerning various kinds of forest use to be limited, and may contribute to increase the sense of social responsibility for the "shared" forests.

Educating society about forestry management rules, the need to carry out forest works and the principles of responsible forest use is the second important solution for reducing the inappropriate use of forest resources, social conflicts and dissatisfaction concerning the forest appearance $[53,59,155]$. Depending on the country's forest organization system, such education may be provided at national and/or local level. For example, the State Forests in Poland managing about 7 million ha of forests, from which about 0.6 million ha are suburban forests, provide education about forests, forestry management and responsible forest use, to over 2 million people annually [86]. At the local level, education may focus on major problems relative to the given region, for example, littering (e.g., actions aimed at collection of waste [38,82]), forest fires [136], unleashed dogs [53], lack of acceptance for restrictions [52], or lack of public understanding of forest management rules (e.g., informing the society about planned forestry works, consultations on social needs, access to planning materials, as well as organization of meetings with city dwellers or trips with foresters to the forest, to explain the objectives and methods of forest management $[53,54,153,156])$.

The third mentioned above type of action for reducing social conflicts and dissatisfaction is the implementation of technical (infrastructural) solutions. Management of the forest edge zone is of major importance, as recreational traffic is usually most intensive in this zone $[37,40]$. In the forest interior, the recommended infrastructure should correspond with the most popular form of use of urban forest, i.e., usually walking (e.g., [25,31,38,39]). In this case, a dense network of paths, roads, and open habitats is favourable [54]. A large number of walking and cycling trails may help to solve at least partly the problem of crowding and the associated negative feelings of forest users [24,25,31,61,62]. The presence of recreational infrastructure in urban forests is usually positively evaluated by their users, however this is not a rule, as some visitors prefer unmanaged forests $[6,31,37,40,75]$. This shows the need for earlier assessment of social preferences in this respect, and their periodical verification [31]. In practice, 
the search for solutions to all the presented problems should refer to local conditions and should take into account their specificity as well as scale [14].

The presented findings are expected to be practical and useful for the management of urban and suburban forests, regardless of location, as a type of checklist of possible problems, to check whether they are important and up-to-date in a particular location. Such control shall take place during the preparation period before a new forest management plan is drawn up, as well as before planned modifications to an already approved plan are made. It is an open list, that can be improved and completed with further items on the basis of practical experience and any other further described problems related to the management and social use of woodlands. Together with an analogous list of pressures and threats to nature related to human activities [67], they will constitute a complete list of possible problems related to the maintenance of European urban and suburban forests.

Funding: The costs of translation of the manuscript into English and of its publishing in open access were covered by the Faculty of Forestry, Warsaw University of Life Sciences (SGGW).

Acknowledgments: The author wishes to thank the anonymous reviewers for their comments, which greatly helped to improve the paper.

Conflicts of Interest: The author declares no conflict of interest. The founding sponsor had no role in the design of the study; in the collection, analyses, or interpretation of data; in the writing of the manuscript, and in the decision to publish the results.

\section{References}

1. Konijnendijk, C.C. Urban Forestry in Europe: A Comparative Study of Concepts, Policies and Planning for Forest Conservation, Management and Development in and around Major European Cities. Ph.D. Thesis, Faculty of Forestry, University of Joensuu, Joensuu, Finland, 1999. Research Notes No. 90.

2. Hunter, I.R. What do people want from urban forestry?-The European experience. Urban Ecosyst. 2001, 5, 277-284. [CrossRef]

3. Jaszczak, R.; Wajchman, S. Wybrane aspekty gospodarki leśnej w lasach miejskich Poznania i w Lasach Państwowych [Selected aspects of forest management in the urban forests of the city of Poznań and the State Forests in Poland]. Sylwan 2015, 159, 160-167. [CrossRef]

4. Jaszczak, R. Uwarunkowania leśnictwa miejskiego i funkcje lasów miejskich w Polsce [Determinants of urban forestry and functions of urban forests in Poland]. In Komunikacja Społeczna w Leśnictwie [Social Communication in Forestry]; Grzywacz, A., Ed.; PTL: Cetniewo k. Władysławowa, Poland, 2016; pp. 131-146. ISBN 978-83-9414444-4-9.

5. Gundersen, V.; Frivold, L.H.; Löfström, I.; Jørgensen, B.B.; Falck, J.; Øyen, B.-H. Urban woodland management-The case of 13 major Nordic cities. Urban For. Urban Green. 2005, 3, 189-202. [CrossRef]

6. Eriksson, L.; Nordlund, A.; Olsson, O.; Westin, K. Beliefs about urban fringe forests among urban residents in Sweden. Urban For. Urban Green. 2012, 11, 321-328. [CrossRef]

7. Gołos, P. The recreational functions of Warsaw's urban and suburban forests. For. Res. Pap. 2013, 74, 57-70. [CrossRef]

8. Hołowiecka, B.; Grzelak-Kostulska, E. Atrakcyjność turystyczna lasów w kontekście nowych tendencji i trendów w turystyce [Forests tourist attractiveness in the context of the new tendencies and trends in tourism]. Stud. Mater. Cent. Eduk. Przyr. Leśnej 2013, 37, 111-117.

9. Tyrväinen, L.; Pauleit, S.; Seeland, K.; de Vries, S. Benefits and Uses of Urban Forests and Trees. In Urban Forests and Trees; Konijnendijk, C., Nilsson, K., Randrup, T., Schipperijn, J., Eds.; Springer: Berlin/Heidelberg, Germany, 2005; pp. 81-114. ISBN 978-3-540-25126-2. [CrossRef]

10. Gołos, P.; Referowska-Chodak, E. Struktura pozaprodukcyjnych funkcji lasu i ich wpływ na sytuacje ekonomiczna gospodarki leśnej [Structure of non-productive forest functions and their impact on the economic situation of forest management]. In Strategia rozwoju lasów i leśnictwa w Polsce do roku 2030 [Strategy for Forest and Forestry Development in Poland by 2030]; Sawicki, A., Szewczykiewicz, G., Szujecka, G., Eds.; IBL: Sękocin Stary, Poland, 2011; pp. 235-266. ISBN 978-83-62830-01-5. 
11. Mattila, O.; Häyrinen, L.; Tervo, M.; Toppinen, A.; Berghäll, S. Challenges of municipal greening and multifunctional forest management: The case of Finland. Urban For. Urban Green. 2015, 14, 982-990. [CrossRef]

12. Hansmann, R.; Hug, S.-M.; Seeland, K. Restoration and stress relief through physical activities in forests and parks. Urban For. Urban Green. 2007, 6, 213-225. [CrossRef]

13. EUROSTAT 2016. Urban Europe-Statistics on Cities, Towns and Suburbs-Green Cities (MS Excel: Green Cities: Tables and Figures). Available online: https://ec.europa.eu/eurostat/statistics-explained/index.php/ Urban_Europe_-_statistics_on_cities,_towns_and_suburbs_-_green_cities (accessed on 28 August 2018).

14. Pauleit, S.; Jones, N.; Nyhuus, S.; Pirnat, J.; Salbitano, F. Urban Forest Resources in European Cities. In Urban Forests and Trees; Konijnendijk, C.C., Nilsson, K., Randrup, T., Schipperijn, J., Eds.; Springer: Berlin/Heidelberg, Germany, 2005; pp. 49-80. ISBN 978-3-540-25126-2. [CrossRef]

15. Gälzer, R. Vergleich der Grünsysteme Europäischer Großstädte Mit Jenem von Wien (Comparison of the Green Systems of Major European Cities with the System of Vienna); Vol. Beiträge zur Stadtforschung, Stadtentwicklung und Stadtgestaltung; Magistratsabteilung: Wien, Austria, 1987.

16. Casalegno, S. Urban and Peri-Urban Tree Cover in European Cities: Current Distribution and Future Vulnerability Under Climate Change Scenarios. In Global Warming Impacts—Case Studies on the Economy, Human Health, and on Urban and Natural Environments; Casalegno, S., Ed.; InTech: Rijeka, Croatia, 2011; pp. 93-108. ISBN 978-953-307-785-7.

17. Millenium Ecosystem Assessment. Ecosystems and Human Well-Being: Synthesis; Island Press: Washington, DC, USA, 2005; ISBN 1-59726-040-1.

18. Alcamo, J.; Bennett, E.M.; Millennium Ecosystem Assessment (Program) (Eds.) Ecosystems and Human Well-Being: A Framework for Assessment; Island Press: Washington, DC, USA, 2003; ISBN 978-1-55963-402-1.

19. Kuchelmeister, G.; Braatz, S. Nouveau regard sur la foresterie urbaine. Unasylva 1993, 173, 3-12. (In French)

20. Murray, S. Gérer les influences forestières dans les zones urbaines et périurbaines. Unasylva 1996, 185, 38-44. (In French)

21. Coles, R.W.; Bussey, S.C. Urban forest landscapes in the UK-Progressing the social agenda. Landsc. Urban Plan. 2000, 52, 181-188. [CrossRef]

22. Tyrväinen, L. Economic valuation of urban forest benefits in Finland. J. Environ. Manag. 2001, 62, 75-92. [CrossRef] [PubMed]

23. Tyrväinen, L.; Mäkinen, K.; Schipperijn, J. Tools for mapping social values of urban woodlands and other green areas. Landsc. Urban Plan. 2007, 79, 5-19. [CrossRef]

24. Arnberger, A.; Eder, R. Exploring coping behaviours of Sunday and workday visitors due to dense use conditions in an urban forest. Urban For. Urban Green. 2012, 11, 439-449. [CrossRef]

25. Arnberger, A. Recreation use of urban forests: An inter-area comparison. Urban For. Urban Green. 2006, 4, 135-144. [CrossRef]

26. Gołos, P. Społeczne znaczenie publicznych funkcji lasu-Pożądany dla rekreacji i wypoczynku model drzewostanu i lasu [Social importance of public forest functions-desirable for recreation model of tree stand and forest]. For. Res. Pap. 2010, 71, 149-164. [CrossRef]

27. Siembida, A. Lasy na obszarach zurbanizowanych: Potrzeby, problemy, wizja rozwoju [Forests in urban areas: Needs, problems, vision of development]. In Rozwój. Lasy i Gospodarka Leśna Jako Instrumenty Ekonomicznego i Społecznego Rozwoju Kraju [Development. Forests and Forest Management as Instruments of Economic and Social Development of the Country]; Kaliszewski, A., Rykowski, K., Eds.; IBL: Sękocin Stary, Poland, 2014; pp. 162-180. ISBN 978-83-62830-44-2.

28. Janeczko, E.; Woźnicka, M. Zagospodarowanie rekreacyjne lasów Warszawy w kontekście potrzeb i oczekiwań mieszkańców stolicy [Development of urban forest recreation of Warsaw in the context of the needs and expectations of the residents of the capital]. Stud. Mater. Cent. Eduk. Przyr. Leśnej 2009, 23, 131-139.

29. Hladnik, D.; Pirnat, J. Urban forestry—Linking naturalness and amenity: The case of Ljubljana, Slovenia. Urban For. Urban Green. 2011, 10, 105-112. [CrossRef]

30. Nordström, E.-M.; Eriksson, L.O.; Öhman, K. Multiple criteria decision analysis with consideration to place-specific values in participatory forest planning. Silva Fenn. 2011, 45, 253-265. [CrossRef]

31. Aasetre, J.; Gundersen, V.; Vistad, O.I.; Holtrop, E.J. Recreational preferences along a naturalness-development continuum: Results from surveys in two unequal urban forests in Europe. J. Outdoor Recreat. Tour. 2016, 16, 58-68. [CrossRef] 
32. Orzechowski, M. Ochrona przyrody i zabytków w rezerwacie Las Natoliński w Warszawie [Protection of environment and monuments in Las Natoliński reserve in Warsaw]. Stud. Mater. Cent. Eduk. Przyr. Leśnej 2007, 16, 254-266.

33. Luniak, M. Fauna of the Big City-Estimating Species Richness and Abundance in Warsaw Poland. In Urban Ecology; Marzluff, J.M., Shulenberger, E., Endlicher, W., Alberti, M., Bradley, G., Ryan, C., Simon, U., ZumBrunnen, C., Eds.; Springer: Boston, MA, USA, 2008; pp. 349-354. ISBN 978-0-387-73411-8. [CrossRef]

34. Orłowski, K.; Martini, K.; Martini, M. Avian responses to undergrowth removal in a suburban wood. Pol. J. Ecol. 2008, 56, 487-495.

35. Gryz, J.; Lesiński, G.; Krauze-Gryz, D.; Stolarz, P. Woodland reserves within an urban agglomeration as important refuges for small mammals. Folia For. Pol. Ser. A For. 2017, 59, 3-13. [CrossRef]

36. Kangas, A.; Heikkilä, J.; Malmivaara-Lämsä, M.; Löfström, I. Case Puijo-Evaluation of a participatory urban forest planning process. For. Policy Econ. 2014, 45, 13-23. [CrossRef]

37. Gundersen, V.; Tangeland, T.; Kaltenborn, B.P. Planning for recreation along the opportunity spectrum: The case of Oslo, Norway. Urban For. Urban Green. 2015, 14, 210-217. [CrossRef]

38. Vítková, M. How do Czechs see urban forests? J. For. Sci. 2006, 52, 565-579. [CrossRef]

39. Heyman, E.; Gunnarsson, B.; Stenseke, M.; Henningsson, S.; Tim, G. Openness as a key-variable for analysis of management trade-offs in urban woodlands. Urban For. Urban Green. 2011, 10, 281-293. [CrossRef]

40. Pourias, J. Un aperçu des problématiques d'actualité en foresterie urbaine: l'exemple des forêts urbaines nantaises. Rev. For. Française 2009, 5, 513-520, [in French with English summary]. [CrossRef]

41. Seeland, K.; Moser, K.; Scheuthle, H.; Kaiser, F.G. Public acceptance of restrictions imposed on recreational activities in the peri-urban Nature Reserve Sihlwald, Switzerland. Urban For. Urban Green. 2002, 1, 49-57. [CrossRef]

42. Konijnendijk, C.C. A decade of urban forestry in Europe. For. Policy Econ. 2003, 5, 173-186. [CrossRef]

43. Beckett, K.P.; Freer-Smith, P.H.; Taylor, G. Urban woodlands: Their role in reducing the effects of particulate pollution. Environ. Pollut. 1998, 99, 347-360. [CrossRef]

44. Atmiş, E.; Özden, S.; Lise, W. Urbanization pressures on the natural forests in Turkey: An overview. Urban For. Urban Green. 2007, 6, 83-92. [CrossRef]

45. Magiera, T.; Strzyszcz, Z.; Rachwal, M. Mapping particulate pollution loads using soil magnetometry in urban forests in the Upper Silesia Industrial Region. Poland. For. Ecol. Manag. 2007, 248, 36-42. [CrossRef]

46. Nowak, D.J.; Dwyer, J.F. Understanding the Benefits and Costs of Urban Forest Ecosystems. In Urban and Community Forestry in the Northeast; Kuser, J.E., Ed.; Springer: Dordrecht, The Netherlands, 2007; pp. $25-46$. ISBN 978-1-4020-4288-1. [CrossRef]

47. Jones, K. Strategic Planning for Urban Woodlands in North West England. In Ecology, Planning, and Management of Urban Forests; Carreiro, M.M., Song, Y.-C., Wu, J., Eds.; Springer: New York, NY, USA, 2008; pp. 199-218. ISBN 978-0-387-71424-0. [CrossRef]

48. Modica, M.; Zoboli, R. Vulnerability, resilience, hazard, risk, damage, and loss: A socio-ecological framework for natural disaster analysis. Web Ecol. 2016, 16, 59-62. [CrossRef]

49. Rykowski, K. Komunikacja przez piękno czyli duchowe użytkowanie lasu [Communication through beauty or spiritual use of the forest]. In Komunikacja Społeczna w Leśnictwie [Social Communication in Forestry]; Grzywacz, A., Ed.; PTL: Cetniewo k. Władysławowa, Poland, 2016; pp. 5-20. ISBN 978-83-9414444-4-9. (In Polish)

50. Jansson, M.; Fors, H.; Lindgren, T.; Wiström, B. Perceived personal safety in relation to urban woodland vegetation-A review. Urban For. Urban Green. 2013, 12, 127-133. [CrossRef]

51. Lehvävirta, S.; Rita, H.; Koivula, M. Barriers against wear affect the spatial distribution of tree saplings in urban woodlands. Urban For. Urban Green. 2004, 3, 3-17. [CrossRef]

52. Mikoś, J.; Matyja, W. Problemy związane z rekreacją i wypoczynkiem na terenach leśnych w Nadleśnictwie Wejherowo [Problems related to recreation and leisure in forest areas in the Wejherowo Forest District]. In Komunikacja Społeczna w Leśnictwie [Social Communication in Forestry]; Grzywacz, A., Ed.; PTL: Cetniewo k. Władysławowa, Poland, 2016; pp. 21-32. ISBN 978-83-9414444-4-9. (In Polish)

53. Pleskot, A. Wyzwania dla gospodarki leśnej Nadleśnictwa Gdańsk-Problemy, konflikty, współpraca [Challenges for forest management Gdańsk Forest District-problems, conflicts, cooperation]. In Komunikacja Społeczna w Leśnictwie [Social Communication in Forestry]; Grzywacz, A., Ed.; PTL: Cetniewo k. Władysławowa, Poland, 2016; pp. 33-42. ISBN 978-83-9414444-4-9. (In Polish) 
54. Ważyński, B. Urządzanie i rekreacyjne zagospodarowanie lasu. In Poradnik Leśnika [Planning and Recreational Management of the Forest. Guide for a Forester], 1st ed.; PWRiL: Warsaw, Poland, 2011; ISBN 978-83-09-01068-5.

55. Pszenny, D.; Janeczko, E. Zielony Pierścień Warszawy jako obszar rozwoju turystyki militarnej [The Green Ring of Warsaw as the area of military tourism development]. Stud. Mater. Cent. Edukac. Przyr. Leśnej 2015, 45, 180-188, (In Polish with English Summary).

56. Cieszewska, A. Ocena ruchu turystycznego w Kampinoskim Parku Narodowym w latach 2005-2006 [Evaluation of touristic traffic in Kampinos National Park in the years 2005-2006]. In Trwałość i Efektywność Ochrony Przyrody $w$ Polskich Parkach Narodowych [The Durability and Efficiency of Nature Protection in Polish National Parks]; Andrzejewska, A., Lubański, A., Eds.; KPN: Izabelin, Polska, 2009; pp. 99-112. ISBN 978-83-7585-070-3.

57. Jaszczak, R.; Beker, C.; Gołojuch, P.; Miotke, M. Preconditioning of forest economy in Poland in urban areas. J. Manag. Sustain. Dev. 2011, 29, 107-111.

58. Ode, Å.K.; Fry, G.L.A. Visual aspects in urban woodland management. Urban For. Urban Green. 2002, 1, $15-24$. [CrossRef]

59. Krajter Ostoić, S.; Konijnendijk van den Bosch, C.C.; Vuletić, D.; Stevanov, M.; Živojinović, I.; Mutabdžija-Bećirović, S.; Lazarević, J.; Stojanova, B.; Blagojević, D.; Stojanovska, M.; et al. Citizens' perception of and satisfaction with urban forests and green space: Results from selected Southeast European cities. Urban For. Urban Green. 2017, 23, 93-103. [CrossRef]

60. Tyrväinen, L.; Silvennoinen, H.; Kolehmainen, O. Ecological and aesthetic values in urban forest management. Urban For. Urban Green. 2003, 1, 135-149. [CrossRef]

61. Arnberger, A.; Haider, W. Social effects on crowding preferences of urban forest visitors. Urban For. Urban Green. 2005, 3, 125-136. [CrossRef]

62. Arnberger, A.; Aikoh, T.; Eder, R.; Shoji, Y.; Mieno, T. How many people should be in the urban forest? A comparison of trail preferences of Vienna and Sapporo forest visitor segments. Urban For. Urban Green. 2010, 9, 215-225. [CrossRef]

63. Kupka, I. Recreational load as a driving variable for urban forests. J. For. Sci. 2006, 52, 324-328. [CrossRef]

64. Matuszewska, D. Uwarunkowania, stan i perspektywy użytkowania turystycznego Wielkopolskiego Parku Narodowego w opiniach mieszkańców Puszczykowa [Conditions and prospects of tourist use of the Wielkopolski National Park in the opinions of the inhabitants of Puszczykowo]. In Studia nad Turystyka. Prace Geograficzne i Regionalne [Studies on Tourism. Geographical and Regional Works]; Kurek, W., Faracik, R., Eds.; IGiGP UJ: Kraków, Poland, 2007; pp. 157-167. ISBN 978-83-88424-35-9.

65. Koppen, G.; Sang, A..O.; Tveit, M.S. Managing the potential for outdoor recreation: Adequate mapping and measuring of accessibility to urban recreational landscapes. Urban For. Urban Green. 2014, 13, 71-83. [CrossRef]

66. Ledig, F.T. Human Impacts on Genetic Diversity in Forest Ecosystems. Oikos 1992, 63, 87-108. [CrossRef]

67. Referowska-Chodak, E. Pressures and Threats to Nature Related to Human Activities in European Urban and Suburban Forests. Forests 2019, 10, 765. [CrossRef]

68. Newton, A.C.; Cayuela, C.; Echeverría, C.; Armesto, J.J.; Del Castillo, R.F.; Golicher, D.; Geneletti, D.; Gonzalez-Espinosa, M.; Huth, A.; López-Barrera, F.; et al. Toward integrated analysis of human impacts on forest biodiversity: Lessons from Latin America. Ecol. Soc. 2009, 14, 2. [CrossRef]

69. Kapos, V.; Lysenko, I.; Lesslie, R. Assessing forest integrity and naturalness in relation to biodiversity. In Forest Resources Assessment Programme, Working Paper 54; Forestry Department FAO: Rome, Italy, 2002.

70. Alix-Garcia, J.; Munteanu, C.; Zhao, N.; Potapov, P.V.; Prishchepov, A.V.; Radeloff, V.C.; Krylov, A.; Bragina, E. Drivers of forest cover change in Eastern Europe and European Russia, 1985-2012. Land Use Policy 2016, 59, 284-297. [CrossRef]

71. Bibliographic Database of the Forest Research Institute in Warsaw. Available online: http://weblis.ibles.pl/ libcat/index.html (accessed on 15 April 2018).

72. Scopus (Abstract and Citation Database of Peer-Reviewed Literature). Available online: www.scopus.com (accessed on 2 August 2018).

73. Grebner, D.L.; Bettinger, P.; Siry, J.P. Forest Policies and External Pressures. In Introduction to Forestry and Natural Resources; Elsevier: Amsterdam, The Netherlands, 2013; pp. 359-383. ISBN 978-0-12-386901-2. [CrossRef] 
74. Gudurić, I.; Tomićević, J.; Konijnendijk, C.C. A comparative perspective of urban forestry in Belgrade, Serbia and Freiburg, Germany. Urban For. Urban Green. 2011, 10, 335-342. [CrossRef]

75. Heyman, E. Analysing recreational values and management effects in an urban forest with the visitor-employed photography method. Urban For. Urban Green. 2012, 11, 267-277. [CrossRef]

76. Schmied, A.; Pillmann, W. Tree protection legislation in European cities. Urban For. Urban Green. 2003, 2, 115-124. [CrossRef]

77. Jaszczak, R.; Ważyński, B.; Wajchman-Świtalska, S. Prawne aspekty leśnictwa miejskiego w Polsce [Legal aspects of urban forestry in Poland]. Sylwan 2017, 161, 659-668. [CrossRef]

78. Davies, H.J.; Doick, K.J.; Hudson, M.D.; Schreckenberg, K. Challenges for tree officers to enhance the provision of regulating ecosystem services from urban forests. Environ. Res. 2017, 156, 97-107. [CrossRef] [PubMed]

79. Młynarski, W.; Kaliszewski, A. The current state of forest management in cities and associated problems in the Mazowieckie Province. For. Res. Pap. 2013, 74, 315-321. [CrossRef]

80. Jaszczak, R.; Wajchman-Świtalska, S. Zarządzanie lasami miejskimi w Polsce [Management of urban forests in Poland]. In Komunikacja Społeczna w Leśnictwie [Social Communication in Forestry]; Grzywacz, A., Ed.; PTL: Cetniewo k. Władysławowa, Poland, 2016; pp. 115-130. ISBN 978-83-9414444-4-9.

81. Diamantopoulou, M.J. Filling gaps in diameter measurements on standing tree boles in the urban forest of Thessaloniki, Greece. Environ. Model. Softw. 2010, 25, 1857-1865. [CrossRef]

82. Jaszczak, R. Las i gospodarka leśna w zasięgu oddziaływania miast w Polsce [Forest and forest economy within the range of influence of towns and cities in Poland]. Stud. Mater. Cent. Edukac. Przyr. Leśnej 2008, 19, 152-171.

83. Jagt, A.V.D.; Lawrence, A. Trees and Woods in Scottish Towns: The Role of Local Authorities; Forest Research: Roslin, UK, 2015. [CrossRef]

84. Gustavsson, R.; Hermy, M.; Konijnendijk, C.; Steidle-Schwahn, A. Management of Urban Woodland and Parks-Searching for Creative and Sustainable Concepts. In Urban Forests and Trees; Konijnendijk, C., Nilsson, K., Randrup, T., Schipperijn, J., Eds.; Springer-Verlag: Berlin/Heidelberg, Germany, 2005; pp. 369-397. ISBN 978-3-540-25126-2. [CrossRef]

85. Nielsen, A.B.; Konijnendijk, C.C.; Wiström, B.; Jensen, R.B. Municipal woodland in Denmark: Resources, governance and management. Scand. J. For. Res. 2013, 28, 49-63. [CrossRef]

86. Leśnictwo [Forestry]. Statistical Yearbook. 2017. Available online: http://stat.gov.pl/obszary-tematyczne/ rolnictwo-lesnictwo/lesnictwo/lesnictwo-2017,1,13.html (accessed on 12 April 2018).

87. Nielsen, A.B.; Jensen, R.B. Some visual aspects of planting design and silviculture across contemporary forest management paradigms-Perspectives for urban afforestation. Urban For. Urban Green. 2007, 6, 143-158. [CrossRef]

88. Krajter Ostoić, S.; Konijnendijk van den Bosch, C.C. Exploring global scientific discourses on urban forestry. Urban For. Urban Green. 2015, 14, 129-138. [CrossRef]

89. Jestaedt, M. Experiences in the Management of Urban Recreational Forests in Germany. In Ecology, Planning, and Management of Urban Forests; Carreiro, M.M., Song, Y.-C., Wu, J., Eds.; Springer: New York, NY, USA, 2008; pp. 301-311. ISBN 978-0-387-71424-0. [CrossRef]

90. Gundersen, V.S.; Frivold, L.H. Public preferences for forest structures: A review of quantitative surveys from Finland, Norway and Sweden. Urban For. Urban Green. 2008, 7, 241-258. [CrossRef]

91. Sieghardt, M.; Mursch-Radlgruber, E.; Paoletti, E.; Couenberg, E.; Dimitrakopoulus, A.; Rego, F.; Hatzistathis, A.; Randrup, T.B. The Abiotic Urban Environment: Impact of Urban Growing Conditions on Urban Vegetation. In Urban Forests and Trees; Konijnendijk, C., Nilsson, K., Randrup, T., Schipperijn, J., Eds.; Springer: Berlin/Heidelberg, Germany, 2005; pp. 281-323. ISBN 978-3-540-25126-2. [CrossRef]

92. Egli, S.; Peter, M.; Buser, C.; Stahel, W.; Ayer, F. Mushroom picking does not impair future harvests-Results of a long-term study in Switzerland. Biol. Conserv. 2006, 129, 271-276. [CrossRef]

93. Boa, E.R. Wild edible fungi: A global overview of their use and importance to people (ANNEX 1 Summary of the importance of wild edible fungi by region and country). In Non-Wood Forest Products; Food and Agriculture Organization of the United Nations: Rome, Italy, 2004; ISBN 978-92-5-105157-3.

94. Eren, S.H.; Demirel, Y.; Ugurlu, S.; Korkmaz, I.; Aktas, C.; Güven, F.M.K. Mushroom poisoning: Retrospective analysis of 294 cases. Clinics 2010, 65, 491-496. [CrossRef] [PubMed] 
95. Vasiljević, N.; Radić, B.; Gavrilović, S.; Šljukić, B.; Medarević, M.; Ristić, R. The concept of green infrastructure and urban landscape planning: A challenge for urban forestry planning in Belgrade, Serbia. iForest Biogeosci. For. 2018, 11, 491-498. [CrossRef]

96. Van Elegem, B.; Embo, T.; Lust, N.; Kerkhove, G.; Houthaeve, R. Criteria for the location of urban forests in densely populated and scarsely wooded areas. Silva Gandav. 1997, 62, 51-73. [CrossRef]

97. Asam, C.; Hofer, H.; Wolf, M.; Aglas, L.; Wallner, M. Tree pollen allergens-an update from a molecular perspective. Allergy 2015, 70, 1201-1211. [CrossRef]

98. EEA. Air Quality in Europe-2017 Report; EEA Report No 13/2017; Publications Office of the European Union: Luxembourg, 2017; ISBN 978-92-9213-921-6. [CrossRef]

99. Oswalt, C.M.; Clatterbuck, W.K. Impacts of Air Pollution on the Urban Forest; UT Extension SP 6572005 ; The University of Tennessee: Knoxville, TN, USA, 2005.

100. German Federal Ministry for Economic Cooperation and Development Bundesministerium für wirtschaftliche Zusammenarbeit und Entwicklung (BMZ) Forestry. In Environmental Handbook; Vieweg+Teubner Verlag: Wiesbaden, Germany, 1995; pp. 47-73. ISBN 978-3-663-09950-5. [CrossRef]

101. Jaszczak, R.; Wajchman, S. Udział i rola czynnika społecznego w tworzeniu planów urządzenia lasu w Polsce [Participation and role of the social factor in developing forest management plans in Poland]. Sylwan 2014, 158, 231-240. [CrossRef]

102. Nordström, E.-M.; Eriksson, L.O.; Öhman, K. Integrating multiple criteria decision analysis in participatory forest planning: Experience from a case study in northern Sweden. For. Policy Econ. 2010, 12, 562-574. [CrossRef]

103. Edwards, D.; Jay, M.; Jensen, F.S.; Lucas, B.; Marzano, M.; Montagné, C.; Peace, A.; Weiss, G. Public preferences for structural attributes of forests: Towards a pan-European perspective. For. Policy Econ. 2012, 19, 12-19. [CrossRef]

104. Lakicevic, M.; Srdjevic, Z.; Srdjevic, B.; Zlatic, M. Decision making in urban forestry by using approval voting and multicriteria approval method (case study: Zvezdarska forest, Belgrade, Serbia). Urban For. Urban Green. 2014, 13, 114-120. [CrossRef]

105. Schulzke, R.; Stoll, S. Forests and Forestry in Hesse, Germany: Meeting the Challenge of Multipurpose Forestry. In Ecology, Planning, and Management of Urban Forests; Carreiro, M.M., Song, Y.-C., Wu, J., Eds.; Springer: New York, NY, USA, 2008; pp. 293-300. ISBN 978-0-387-71424-0. [CrossRef]

106. Górecka, A. Funkcja rekreacyjna warszawskiego Lasu Bielańskiego [Recreation function of Warsaw Bielański Forest]. Stud. Mater. Cent. Edukac. Przyr. Leśnej 2009, 23, 172-179.

107. Skłodowski, J.; Gołos, P. Preferowany typ drzewostanu i czynniki decydujące o atrakcyjności turystycznej drzewostanu w opinii społecznej [Preferred type of forest stand and factors deciding about the tourist attractiveness of the forest]. Sylwan 2015, 159, 747-756. [CrossRef]

108. Grandy, J.W.; Stallman, E.; Macdonald, D. The science and sociology of hunting: Shifting practices and perceptions in the United States and Great Britain. In The State of the Animals II: 2003; Salem, D.J., Rowan, A.N., Eds.; Humane Society Press: Washington, DC, USA, 2003; pp. 107-130. ISBN 978-0-9658942-7-2.

109. Bussey, S.C.; Coles, R.W. The structure and community use of an urban forest. Q. J. For. 1995, 89, $182-191$.

110. Edwards, D.M.; Jay, M.; Jensen, F.S.; Lucas, B.; Marzano, M.; Montagné, C.; Peace, A.; Weiss, G. Public Preferences Across Europe for Different Forest Stand Types as Sites for Recreation. Ecol. Soc. 2012, 17, 27. [CrossRef]

111. Nielsen, A.B.; Møller, F. Is coppice a potential for urban forestry? The social perspective. Urban For. Urban Green. 2008, 7, 129-138. [CrossRef]

112. Tomalak, M. Postrzeganie drzew, szkodników oraz zabiegów ochrony roślin na obszarach parków i lasów miejskich [Citizen's perception of trees, tree pests and pest management-related activity in urban parks and forests]. Prog. Plant Prot. 2006, 46, 337-343.

113. Skwarek, K.; Bijak, S. Resources of dead wood in the municipal forests in Warsaw. For. Res. Pap. 2015, 76, 322-330. [CrossRef]

114. Verlič, A.; Arnberger, A.; Japelj, A.; Simončič, P.; Pirnat, J. Perceptions of recreational trail impacts on an urban forest walk: A controlled field experiment. Urban For. Urban Green. 2015, 14, 89-98. [CrossRef]

115. Calaza Martínez, P. Trees in urban ecosystem: Connection between new urbanism, society and rational risk management. Ing. Univ. 2015, 20, 155-174. [CrossRef] 
116. Seidling, W.; Travaglini, D.; Meyer, P.; Waldner, P.; Fischer, R.; Granke, O.; Chirici, G.; Corona, P. Dead wood and stand structure-Relationships for forest plots across Europe. iForest Biogeosci. For. 2014, 7, 269-281. [CrossRef]

117. Brumelis, G.; Jonsson, B.; Kouki, J.; Kuuluvainen, T.; Shorohova, E. Forest naturalness in northern Europe: Perspectives on processes, structures and species diversity. Silva Fenn. 2011, 45, 807-821. [CrossRef]

118. Pastorella, F.; Avdagić, A.; Čabaravdić, A.; Mraković, A.; Osmanović, M.; Paletto, A. Tourists' perception of deadwood in mountain forests. Ann. For. Res. 2016, 59, 311-326. [CrossRef]

119. Puletti, N.; Giannetti, F.; Chirici, G.; Canullo, R. Deadwood distribution in European forests. J. Maps 2017, 13, 733-736. [CrossRef]

120. Hoffmaster, E.; Vonk, J.; Mies, R. Education to Action: Improving Public Perception of Bats. Animals 2016, 6, 6. [CrossRef] [PubMed]

121. Bjerke, T.; Østdahl, T. Animal-related attitudes and activities in an urban population. Anthrozoös 2004, 17, 109-129. [CrossRef]

122. Calzolari, M. Mosquito-borne diseases in Europe: An emerging public health threat. Rep. Parasitol. 2016, 5, 1-12. [CrossRef]

123. Charrel, R.N.; Attoui, H.; Butenko, A.M.; Clegg, J.C.; Deubel, V.; Frolova, T.V.; Gould, E.A.; Gritsun, T.S.; Heinz, F.X.; Labuda, M.; et al. Tick-borne virus diseases of human interest in Europe. Clin. Microbiol. Infect. 2004, 10, 1040-1055. [CrossRef]

124. Chippaux, J.-P. Epidemiology of snakebites in Europe: A systematic review of the literature. Toxicon 2012, 59, 86-99. [CrossRef]

125. Barua, M.; Bhagwat, S.A.; Jadhav, S. The hidden dimensions of human-wildlife conflict: Health impacts, opportunity and transaction costs. Biol. Conserv. 2013, 157, 309-316. [CrossRef]

126. Tahvanainen, L.; Tyrväinen, L.; Ihalainen, M.; Vuorela, N.; Kolehmainen, O. Forest management and public perceptions-Visual versus verbal information. Landsc. Urban Plan. 2001, 53, 53-70. [CrossRef]

127. Gołos, P.; Zając, S. Delimitacja rekreacyjnej funkcji lasów i gospodarki leśnej na terenach zurbanizowanych [Assignment of recreational function to forests and forest management in urban areas]. For. Res. Pap. 2011, 72, 83-94. [CrossRef]

128. Clark, K.E. Attracting and Managing for Wildlife. In Handbook of Urban and Community Forestry in the Northeast; Kuser, J.E., Ed.; Springer: Boston, MA, USA, 2000; pp. 397-409. ISBN 978-1-4613-6880-9. [CrossRef]

129. Faulkner, S. Urbanization impacts on the structure and function of forested wetlands. Urban Ecosyst. 2004, 7,89-106. [CrossRef]

130. Pedrotti, F. Types of Vegetation Maps. In Plant and Vegetation Mapping; Springer: Berlin/Heidelberg, Germany, 2013; pp. 103-181. ISBN 978-3-642-30234-3. [CrossRef]

131. Del Castillo, R.F.; Argueta, S.T.; Sáenz-Romero, C. Pinus chiapensis, a keystone species: Genetics, ecology, and conservation. For. Ecol. Manag. 2009, 257, 2201-2208. [CrossRef]

132. Bergstedt, J.; Milberg, P. The impact of logging intensity on field-layer vegetation in Swedish boreal forests. For. Ecol. Manag. 2001, 154, 105-115. [CrossRef]

133. Radeloff, V.C.; Mladenoff, D.J.; Gustafson, E.J.; Scheller, R.M.; Zollner, P.A.; He, H.S.; Akçakaya, H.R. Modeling forest harvesting effects on landscape pattern in the Northwest Wisconsin Pine Barrens. For. Ecol. Manag. 2006, 236, 113-126. [CrossRef]

134. MCPFE The Updated Pan-European Indicators for Sustainable Forest Management (Leaflet). 2017. Available online: https://foresteurope.org/wp-content/uploads/2017/03/CI_4pages.pdf (accessed on 31 August 2018).

135. Ważyński, B. Urzadzanie i Zagospodarowanie Lasu dla Potrzeb Turystyki i Rekreacji [Planning and Management of the Forest for Tourism and Recreation], 4th ed.; Akademia Rolnicza: Poznań, Poland, 1997; ISBN 83-7160-065-8.

136. Lehvävirta, S. Non-anthropogenic dynamic factors and regeneration of (hemi)boreal urban woodlandsSynthesising urban and rural ecological knowledge. Urban For. Urban Green. 2007, 6, 119-134. [CrossRef]

137. Ivancević, B.; Matavulj, M.; Vukojević, J.; Karaman, M. Fungi in the legislation of the Republic of Serbia. Matica Srpska Proc. Nat. Sci. 2012, 123, 51-64. [CrossRef]

138. Sreetheran, M.; van den Bosch, C.C.K. A socio-ecological exploration of fear of crime in urban green spaces-A systematic review. Urban For. Urban Green. 2014, 13, 1-18. [CrossRef]

139. Levin, S.A. Public goods in relation to competition, cooperation, and spite. Proc. Natl. Acad. Sci. USA 2014, 111, 10838-10845. [CrossRef] 
140. Lee, J.; Tsunetsugu, Y.; Takayama, N.; Park, B.-J.; Li, Q.; Song, C.; Komatsu, M.; Ikei, H.; Tyrväinen, L.; Kagawa, T.; et al. Influence of Forest Therapy on Cardiovascular Relaxation in Young Adults. Evid. Based Complement. Altern. Med. 2014, 2014, 1-7. [CrossRef]

141. Li, Q.; Kawada, T. Effect of Forest Therapy on the Human Psycho-Neuro-Endocrino-Immune Network. Nippon Eiseigaku Zasshi Jpn. J. Hyg. 2011, 66, 645-650. [CrossRef] [PubMed]

142. Dudek, K.; Jerzak, L.; Tryjanowski, P. Zwierzęta Konfliktowe w Miastach [Conflict Animals in Cities], 1st ed.; RDOŚ: Gorzów Wielkopolski, Poland, 2016; ISBN 978-83-63564-02-5.

143. Troy, A.; Morgan Grove, J.; O'Neil-Dunne, J. The relationship between tree canopy and crime rates across an urban-rural gradient in the greater Baltimore region. Landsc. Urban Plan. 2012, 106, 262-270. [CrossRef]

144. Bogar, S.; Beyer, K.M. Green Space, Violence, and Crime: A Systematic Review. Trauma Violence Abus. 2016, 17, 160-171. [CrossRef] [PubMed]

145. Tedim, F.; Xanthopoulos, G.; Leone, V. Forest Fires in Europe: Facts and Challenges. In Wildfire Hazards, Risks and Disasters; Shroder, J.F., Paton, D., Eds.; Elsevier: Amsterdam, The Netherlands, 2015; pp. 77-99. ISBN 978-0-12-410434-1. [CrossRef]

146. Bekoff, M.; Meaney, C.A. Interactions among dogs, people, and the environment in Boulder, Colorado: A case study. Anthrozoös 1997, 10, 23-31. [CrossRef]

147. Thompson, I.D.; Guariguata, M.R.; Okabe, K.; Bahamondez, C.; Nasi, R.; Heymell, V.; Sabogal, C. An operational framework for defining and monitoring forest degradation. Ecol. Soc. 2013, 18, 20. [CrossRef]

148. Skłodowski, J.; Bartosz, S.; Dul, Ł.; Grzybek, D.; Jankowski, S.; Kajetanek, M.; Kalisz, P.; Korenkiewicz, U.; Mazur, G.; Myszek, J.; et al. Próba oceny wpływu szerokości szlaków turystycznych na otaczające je środowisko lasu [An attempt to assess the effect of tourist trail width on adjacent forest environment]. Sylwan 2009, 153, 699-709. [CrossRef]

149. Malmivaara, M.; Löfström, I.; Vanha-Majamaa, I. Anthropogenic effects on understorey vegetation in Myrtillus type urban forests in southern Finland. Silva Fenn. 2002, 36, 367-381. [CrossRef]

150. Weston, M.A.; Stankowich, T. Dogs as agents of disturbance. In Free-Ranging Dogs and Wildlife Conservation; Gompper, M.E., Ed.; Oxford University Press: Oxford, UK; New York, NY, USA, 2014; pp. 94-116. ISBN 978-0-19-966321-7.

151. Van Elegem, B.; Embo, T.; Muys, B.; Lust, N. A methodology to select the best locations for new urban forests using multicriteria analysis. Forestry 2002, 75, 13-23. [CrossRef]

152. Johnston, M. The development of urban forestry in Northern Ireland. Irish For. 1998, 55, 37-58.

153. Sipilä, M.; Tyrväinen, L. Evaluation of collaborative urban forest planning in Helsinki, Finland. Urban For. Urban Green. 2005, 4, 1-12. [CrossRef]

154. Nordström, E.-M.; Romero, C.; Eriksson, L.O.; Öhman, K. Aggregation of preferences in participatory forest planning with multiple criteria: An application to the urban forest in Lycksele, Sweden. Can. J. For. Res. 2009, 39, 1979-1992. [CrossRef]

155. Jones, N. Approaches to Urban Forestry in the United Kingdom. In Ecology, Planning, and Management of Urban Forests; Carreiro, M.M., Song, Y.-C., Wu, J., Eds.; Springer: New York, NY, USA, 2008; pp. 109-117. ISBN 978-0-387-71424-0. [CrossRef]

156. Nichnadowicz, J. Community Involvement in Urban Forestry Programs. In Handbook of Urban and Community Forestry in the Northeast; Kuser, J.E., Ed.; Springer: Boston, MA, USA, 2000; pp. 121-135. ISBN 978-1-4613-6880-9. [CrossRef]

(C) 2019 by the author. Licensee MDPI, Basel, Switzerland. This article is an open access article distributed under the terms and conditions of the Creative Commons Attribution (CC BY) license (http://creativecommons.org/licenses/by/4.0/). 